\title{
Proteção do consumidor no âmbito do comércio eletrônico*
}

\author{
Claudia Lima Marques**
}

\section{INTRODUÇÃO}

Autores alemães denominam o comércio eletrônico de "colocação eletrônica à distância" de produtos e serviços ("elektronische Fernabsatz"), ${ }^{1}$ de "negócio eletrônico" (elektronische Geschaeftsverkehr), ${ }^{2}$ ou de negó- cios através da Internet (Geschaeftsverkehr über das Internet) ${ }^{3}$ A doutrina brasileira prefere denominá-los "contratos eletrônicos", ${ }_{4}$ "contratos por computador" ${ }^{\prime}$ Efetivamente, desde a década de 90 , há um espaço novo de comércio, ${ }^{6}$ que é a Internet, as redes eletrônicas e de telecomunicação

* Conferência apresentada no Painel Direitos do Consumidor, dia 12 de novembro de 2002, na XVIII Conferência Nacional dos Advogados - Cidadania, Ética e Estado, em Salvador da Bahia, organizada pelo Conselho Federal da OAB.

** Professora da Faculdade de Direito da Universidade Federal do Rio Grande do Sul, Porto Alegre, Brasil, Doutora em Direito pela Universidade de Heidelberg, Alemanha, Mestre em Direito Civil e Direito Internacional Privado pela Universidade de Tübingen, Alemanha, Especialista em Integração Européia pela Universidade de Saarbrücken, Alemanha, Diretora do Instituto Brasileiro de Política e Defesa do Consumidor - BRASILCON.

1 REICH, Norbert; NORDHAUSEN, Annette. Verbraucher und Recht in Elektronischen Verkehr (eG). Baden-Baden: Nomos, 2000. p. 36.

2 STECKLER, Brunhilde. Grundzüge des EDV-Rechts. Munique: Vahlen, 1999. p. 200.

3 WIMMER, Norbert; GERHARD, Michael. Der Online-Provider im neunen Multimediarecht. Baden-Baden: Nomos, 1998. p. 135.

4 Veja SANTOS, Manoel J. Pereira dos e ROSSI, Maria Delapieve. Aspectos legais do comércio eletrônico, $R D C, 35,2000$, p. 123 e seg. Estes autores, p. 108, definem contratos eletrônicos como os "negócios jurídicos bilaterais que utilizam o computador, como mecanismo responsável pela formação e instrumentalização do vínculo contratual".

5 SANTOLIM, Cesar Viterbo Matos. Formação e Eficácia Probatória dos Contratos por Computador. São Paulo: Saraiva, 1995, p. 21 e seg.

6 Como ensina STECKLER, p. 278, os meios usados para esta contratação à distância podem ser o telefone (com pessoas ou gravações, voice-mail, audiotexte etc.), rádio ou telefone com 
de massa. ${ }^{7}$ Trata-se do denominado "comércio eletrônico", comércio realizado através de contratações à distância, as quais são conduzidas por meios eletrônicos (e-mail, etc.), por Internet (on-line) ou por meios de telecomunicações de massa (telemarketing, TV, TV a cabo, etc.), sem a presença física simultânea dos dois contratantes no mesmo lugar (e sim à distância). ${ }^{8}$ Daí ter denominado estes contratos de contratos à distância no comércio eletrônico. ${ }^{9}$

O novo Código, recém aprovado em 10 de janeiro de 2002, nada menciona sobre os contratos de comércio eletrônico, mas não desconhece os meios eletrônicos de reprodução (Art. 225 refe- rente à prova $)^{10} \mathrm{e}$ de arquivo (Art. 1180 sobre escrituração). ${ }^{11}$

A nova Lei 10.406 de 2002 também não conhece as expressões 'Internet', nem contratação 'à distância', mas regula a contratação entre ausentes sob a mesma tradicional orientação do Código Civil de 1916 (veja art. 1086 do CC/ 16), de acordo com a teoria da expedição da aceitação (veja o novo Art. 434). ${ }^{12}$

O Código Civil de 2002 inova ao unificar as obrigações civis e empresariais, mas mantém a linha do Art. 1081 do CC/16 ao estabelecer para todas estas relações jurídicas, civis e empresariais, entre ausentes e presentes, a possibilidade de revogação da proposta já realizada (Art. 428). ${ }^{13}$ Ao

imagens, videotexto, microcomputadores, televisão, com teclado ou tela de contato, e-mail, telefax, teleshoping e outras técnicas semelhantes.

7 Note-se que a Lei Modelo da UNCITRAL para o comércio eletrônico (UNCITRAL Model Law on Eletronic Commerce), que é voltada para o comércio internacional e inter-empresários, tanto que sua nota de rodapé 1 explicita que as normas previstas não revogam ou atingem qualquer norma visando a proteção dos consumidores (** This Law does not override any rule of law intended for the protection of consumers), define em seu art. $2^{\circ}$ que o comércio eletrônico tem como base a transferência de computador para computador (EDI) de informações usando um código standard para estruturar a informação (Art.2, b - "Eletronic data interchangeEDI" means the eletronic transfer from computer to computer of information using an agreed standard to structure the information) e que os dados transferidos são informações geradas, enviadas, recebidas ou guardadas em forma ou meio eletrônico, óptico ou similar (Art. 2, a"Data message" means informations generated, sent, received or stored by eletronic, optical or similar means including, but not limited to, eletronic data interchange (EDI), eletronic mail, telegram, telex or telecopy), Veja Law Commision, part one, p.139 e 140.

8 Elementos retirados da Diretiva 97/7/CE, de 20 de maio de 1997, sobre contratação à distância (Widmer/Baehler, p. 179 e seg.) e dos comentários de REICHORDHAUSEN, p. 36.

9 MARQUES, Claudia Lima, Contratos no Código de Defesa do Consumidor. São Paulo: RT, 2002, p. 97 e seg.

100 texto original é: “Art. 225. As reproduções fotográficas, cinematográficas, os registros fonográficos e, em geral, quaisquer outras reproduções mecânicas ou eletrônicas de fatos ou de coisas fazem prova plena destes, se a parte, contra quem forem exibidos, não lhes impugnar a exatidão." 110 texto original é "Art. 1.180. Além dos demais livros exigidos por lei, é indispensável o Diário, que pode ser substituído por fichas no caso de escrituração mecanizada ou eletrônica."

12 O texto original é: "Art. 434. Os contratos entre ausentes tornam-se perfeitos desde que a aceitação é expedida, exceto: I - no caso do artigo antecedente; II - se o proponente se houver comprometido a esperar resposta; III - se ela não chegar no prazo convencionado."

13 O texto original é: "Art. 428. Deixa de ser obrigatória a proposta: I - se, feita sem prazo a pessoa presente, não foi imediatamente aceita. Considera-se também presente a pessoa 
permitir que se limite ou revogue a proposta, revela, assim, a nova lei o apreço ao poder de autodeterminação para existir a autovinculação (em alemão, Selbstbestimmung - Selbstbindung), privilegiando a teoria da vontade (Art.112) ${ }^{14}$ e não as teorias da declaração ou da confiança (veja art. 30 e 35 do Código de Defesa do Consumidor). No novo sistema geral do CC/2002, é pequeno o grau de vinculação, que esta declaração do proponente visando um contrato possui (Art. 427), ${ }^{15}$ mesmo considerando-se que o CC/2002 expressamente prevê que a falta de comunicação entre os futuros contratantes pode levar à reparação dos eventuais danos (Art. 430). ${ }^{16}$

No CC/2002, a retirada da proposta por parte do proponente não é considerada, porém, per se como um dano, apesar da confiança despertada. Assim, mesmo sendo a proposta uma "oferta pública" pode o proponente retirá-la, se reservou esta opção expressamente na oferta e se o fizer através do mesmo meio usado para atingir ao público (Art.
439). ${ }^{17}$ Esta regra 'conflita' com o determinado no Código de Defesa do Consumidor (Art. 30, 35, 36 e 37 do CDC), segundo o qual a oferta ao público de consumo, que cria confiança, não pode ser 'retirada', nem sequer por erro na publicidade ou por uso do mesmo meio. A oferta no sistema do CDC vincula e integra o futuro contrato (Art. 30 do CDC), podendo o consumidor exigir seu cumprimento, a rescisão com perdas e danos e a entrega de coisa semelhante (Art. 35 do CDC).

Se o CDC, lei especial, dispõe de uma forma, e a nova lei geral dispõe diferentemente, a pergunta resultante é que norma prevalecerá, a da lei especial ou a da lei geral posterior. A pergunta implícita é se estas normas realmente estão em conflito. Esta pergunta da existência ou não de conflito não deve ser subestimada, pois o novo CC e o CDC têm campos de aplicação diferentes, uma lei tutelar, principiológica, de origem constitucional (Art. 48 ADCT e Art. $5^{\circ}$, XXXII da CF/88), centrada pós-modernamente na prote-

que contrata por telefone ou por meio de comunicação semelhante; II - se, feita sem prazo a pessoa ausente, tiver decorrido tempo suficiente para chegar a resposta ao conhecimento do proponente; III - se, feita a pessoa ausente, não tiver sido expedida a resposta dentro do prazo dado; IV - se, antes dela, ou simultaneamente, chegar ao conhecimento da outra parte a retratação do proponente."

14 Texto original é: "Art. 112. Nas declarações de vontade se atenderá mais à intenção nelas consubstanciada do que ao sentido literal da linguagem."

15 O texto original é: "Art. 427. A proposta de contrato obriga o proponente, se o contrário não resultar dos termos dela, da natureza do negócio, ou das circunstâncias do caso."

$16 O$ texto original é: "Art. 430. Se a aceitação, por circunstância imprevista, chegar tarde ao conhecimento do proponente, este comunicá-lo-á imediatamente ao aceitante, sob pena de responder por perdas e danos."

17 O texto original é: "Art. 429. A oferta ao público equivale a proposta quando encerra os requisitos essenciais ao contrato, salvo se o contrário resultar das circunstâncias ou dos usos.Parágrafo único. Pode revogar-se a oferta pela mesma via de sua divulgação, desde que ressalvada esta faculdade na oferta realizada." 
ção do sujeito vulnerável, no diferente, no sujeito mais fraco na relação fornecedor-consumidor e com campo de aplicação rationae personae difuso, coletivo, individual homogêneo e individual puro; outra uma lei moderna, geral, centrada na igualdade entre civis e empresários nas suas relações civis puras e interempresárias.

Certo é que o comércio eletrônico hoje é realizado mais entre empresários (Business-to-Business ou $\mathrm{B} 2 \mathrm{~B}$ ), mas a tendência é que o contratação eletrônica entre fornecedores e consumidores (Business-to-Consumer ou B2C) também cresça. ${ }^{18}$ Guido Alpa, na edição de 2002 de seu livro sobre o direito dos consumidores, é enfático na necessidade de proteger de forma eficiente os consumidores também quando eles utilizamse do meio eletrônico para contratar. ${ }^{19}$ O Código Civil alemão (BGB), reformado em 2000 e 2001, incluiu agora normas que reproduzem as linhas das Diretivas sobre proteção dos contratantes nos contratos à distância e no comércio eletrônico, em especial se são consumidores ( $§ 13$ do BGB-reformado). A doutri- na mundial é unânime que a interpretação dos contratos do comércio eletrônico envolvendo consumidores deve ser diferenciada, sensível à proteção do contratante mais fraco e leigo, o consumidor. ${ }^{20}$ Temos que saber, pois, a partir de janeiro de 2003 que normas se aplicam à contratação eletrônica civil, empresarial e de consumo.

Neste artigo, pois, quero analisar o comércio eletrônico no novo Código Civil e no Código de Defesa do Consumidor, discutindo dois temas: (1) o conflito ou diálogo entre o Código Civil novo e o CDC nesta matéria e (2) quais as normas principais a guiar a conclusão dos contratos pela Internet e a impor os requisitos formais da declaração eletrônica de vontade. ${ }^{21}$

\section{O CONFLITO OU DIÁLOGO ENTRE O CÓDIGO CIVIL E O CDC EM MATÉRIA DE COMÉRCIO ELETRÔNICO}

Em seu curso Geral de Haia, de 1995 , o mestre de Heidelberg, Erik Jayme, ensinava que, face ao atual "pluralis-

18 GAMBOGI CARVALHO, Ana Paula. Contratos via Internet, Belo Horizonte, Del Rey, 2001, p. 20 esclarece que na América Latina, em 2000, já existiam 8,12 milhões de Internautas e no Brasil, 4,25milhões, com previsão que este número em 2003 cresça para mais de 10 milhões.

19 ALPA, Guido. Il Diritto dei consumatori, Roma: Laterza, 2002, p. 360.

20 Assim diferenciam o comércio B2B do B2C: VIVANT, p. 173, FÉRAL-SCHUHL, p. 147 e seg., LORENZETTI, Comeércio Eletrónico, p. 218 e seg., BRIZZIO, p. 42, MAYER/Partie Faible, p. 514 e seg., MEENTSz, p. 179 e seg., REICH/NORDHAUSEN, p. 2 e seg., Köhler/ Arndt, p. 35 e seg., HÄRTING, p. 67 e seg., no Brasil, SANTOLIM, p. 37 e seg., SANTOS e ROSSI, p. 118 e seg., DELUCCA/Internet, p. 89, e seg., SIMÃO, p. 101 e seg., PODESTÁ, p. 162 e seg., LUCON, p. 354 e seg., SENISE, p. 488, LOTUFFO, p. 222, GRECO, Marco Aurélio. Direito e Internet. São Paulo: Dialética, 2000, p. 49 e seg e LUCON, Rodrigo, $A$ Internet e as relações de consumo, SCHOUERI, Luis Eduardo (Org.): o direito na era virtual. Rio de Janeiro: Forense, 2001, p. 3.

21 Veja, para mais detalhes, a obra de GAMBOGI CARVALHO, p. 21 e seg. 
mo pós-moderno" 22 de um Direito com fontes legislativas plúrimas, ressurge a necessidade de coordenação entre as leis no mesmo ordenamento, como exigência para um sistema jurídico eficiente e justo. ${ }^{23}$ Efetivamente, cada vez mais se legisla, nacional e internacionalmente, sobre temas convergentes. A pluralidade de leis é o primeiro desafio do aplicador da lei contemporâneo. A expressão usada em geral era a de "conflitos de leis no tempo", ${ }^{24}$ a significar que haveria uma 'colisão' ou conflito entre os campos de aplicação destas leis. Assim, por exemplo, uma lei anterior, como o Código de Defesa do Consumidor de 1990 e uma lei posterior, como o novo Código Civil Brasileiro de 2002, estariam em 'conflito', daí a necessária 'solução' do 'conflito' através da prevalência de uma lei sobre a outra e a conseqüente exclusão da outra do sis- tema (abrogação, derrogação, revogação).

Em outras palavras, nesta visão "perfeita" ou "moderna", teríamos a "tese" (lei antiga), a "antítese" (lei nova) e a conseqüente síntese (a revogação), a trazer clareza e certeza ao sistema (jurídico). Os critérios para resolver os conflitos de leis no tempo seriam assim apenas três: anterioridade, especialidade e hierarquia, a priorizar-se, segundo Bobbio, a hierarquia. $^{25}$

A doutrina atualizada, porém, está à procura hoje mais da harmonia e da coordenação entre as normas do ordenamento jurídico (concebido como sistema $)^{26}$ do que da exclusão. É a denominada "coerência derivada ou restaurada" ("cohérence dérivée ou restaurée"), ${ }^{27}$ que em um momento posterior à decodificação, à tópica e à micro-recodificação, ${ }^{28}$ procura uma eficiência

22 Segundo Erik Jayme as características, os elementos da cultura pós-moderna no direito seriam: o Pluralismo, a Comunicação, a Narração, o que Jayme denomina de "le retour des sentiments", sendo o Leitmotive da pós-modernidade, a valorização dos direitos humanos. JAYME, Erik. Identité culturelle et intégration: Le droit internationale privé postmoderne. Recueil des Cours de l'Académie de Droit International de la Haye, v.2, 1995, II, p. 36 e seg.

23 JAYME, Recueil des Cours,1995,II, p. 60 e p. $251 \mathrm{e}$ seg.

24 Preferível é a expressão neutra Direito intertemporal, já usada por FRANÇA, R. Limogi. Direito Intertemporal Brasileiro. 2. ed., São Paulo: Revista dos Tribunais, 1968, p. 9 e seg.

25 Veja BOBBIO, Norberto. Teoria do ordenamento jurídico. São Paulo, Brasília: Ed. Pollis, Universidade de Brasília, 1990, p. 92 e BOBBIO, Norberto. Des critères pour résoudre les antinomies", In: PERELMAN, CH. (Coord.), Les Antinomies en Droit. Bruxelas: Bruylant, 1965 , p. 255.

26 Veja SAUPHANOR, Nathalie, L'Influence du Droit de la Consommation sur le système juridique, Paris: LGDJ, 2000, p. 23 a 32.

27 Expressão de SAUPHANOR, p. 32.

28 Mencione-se aqui que a sempre citada obra de CANARIS, Claus-Wilhelm. Pensamento sistemático e conceito de Sistema do Direito. Lisboa: Gulbelkian, 1989, constroi sua idéia de sistema justamente criticando a tópica, p. 255 e seg. sobre tópica veja WIEHWEG, Theodor. 
não só hierárquica, ${ }^{29}$ mas funcional ${ }^{30} \mathrm{do}$ sistema plural e complexo de nosso direito contemporâneo, ${ }^{31}$ a evitar a 'antinomia', a 'incompatibilidade' ou a 'nãocoerência'. ${ }^{32}$

Costumava-se afirmar, quanto ao tipo de conflitos de leis no tempo, que poderiam existir: 'conflitos de princípios' (diferentes princípios presentes em diferentes leis em conflito), "conflitos de normas' (conflitos entre normas de duas leis, conflitos 'reais' ou 'aparentes', conforme o resultado da interpretação que o aplicador das leis retirasse), e 'antinomias' (conflitos 'pontuais' da convergência eventual e parcial do campo de aplicação de duas normas no caso concreto). ${ }^{33}$

Erik Jayme $^{34}$ alerta-nos que os tempos pós-modernos, onde a pluralidade, a complexidade, a distinção impositiva dos direitos humanos e do droit à la differènce (direito a ser diferente e ser tratado dife- rentemente, sem necessidade mais de ser 'igual' aos outros) não mais permitem este tipo de clareza ou de 'mono-solução'. A solução sistemática pós-moderna deve ser mais fluida, mais flexível, a permitir maior mobilidade e fineza de distinções. Nestes tempos, a superação de paradigmas é substituída pela convivência dos paradigmas ${ }^{35}$ a revogação expressa pela incerteza da revogação tácita indireta através da incorporação (veja Art. 2043 do novo Código Civil), há por fim a convivência de leis com campos de aplicação diferentes, campos por vezes convergentes e, em geral diferentes, em um mesmo sistema jurídico, que parece ser agora um sistema (para sempre) plural, fluido, mutável e complexo. ${ }^{36}$ Não deixa de ser um paradoxo que o 'sistema', o todo construído, seja agora plural.... ${ }^{37}$

O grande mestre de Heidelberg propõe então a convivência de uma segun-

Tópica e Jurisprudência. Tradução Tércio S. Ferraz Jr. Brasília: Departamento de Imprensa Nacional, MJ-UnB, 1979.

29 Veja sobre a crise ou neutralização do critério da hierarquia e a utilização de outros critérios, GANNAGé, Léna, La Hiérarchie des Normes et les Méthodes du Droit International Privé. LGDJ, Paris, 2001, p. 25 e 26.

30 SAUPHANOR, p. 30.

31 Veja sobre a necessidade de 'coordinamento con altre disposizioni' do Código Civil e das leis especiais de proteção do consumidor, ALPA, Guido et al., La Disciplina Generale dei Contratti, 8. ed. Torino: Giappichelli, 2001, p. 613 e seg.

32 SAUPHANOR, p. 31.

33 Veja detalhes em meu livro Contratos no Código de Defesa do Consumidor, RT, São Paulo, 2002, p. 515 e seg.

34 JAYME, Recueil des Cours, p. 60 e p. 251.

35 GANNAGÉ, p. 17.

36 Do grande mestre da USP, vem a expressão sistema hiper-complexo, veja AZEVEDO, Antonio Junqueira de $O$ Direito pós-moderno e a codificação, Revista Direito do Consumidor, vol. 33, 2000, p. 124 e seg.

37 Veja a favor do pluralismo jurídico a bela análise de BELLEY, Jean-guy. Le pluralisme juridique comme doctrine de la science du droit. In Pour un Droit Pluriel-Etudes offertes au 
da solução ao lado da tradicional: a coordenação destas fontes. ${ }^{38}$ Uma coordenação flexível e útil (effet utile) das normas em conflito no sistema a fim de restabelecer a sua coerência, isto é, uma mudança de paradigma: da retirada simples (revogação) de uma das normas em conflito do sistema jurídico (ou do 'monólogo' de uma só norma possível a "comunicar" a solução justa), à convivência destas normas, ao diálogo das normas para alcançar a sua ratio, a finalidade "narrada" ou "comunicada" em ambas.
Na belíssima expressão de Erik Jayme, é o atual e necessário 'diálogo das fontes' (dialogue de sources), ${ }^{39}$ a permitir a aplicação simultânea, coerente e coordenada das plúrimas fontes legislativas convergentes. ${ }^{40}$ 'Diálogo' porque há influências recíprocas, 'diálogo' porque há aplicação conjunta das duas normas ao mesmo tempo e ao mesmo caso, seja complementariamente,,$^{41}$ seja subsidiariamente, ${ }^{42}$ seja permitindo a opção voluntária das partes sobre a fonte prevalente (especialmente em maté-

professeur Jean-François Perrin. Genbra: Helbing \& Lichtenhahn, 2002, p. 135 e seg. No Brasil, veja Fachin, Luiz Edson. Transformações do direito civil brasileiro contemporâneo, In: Diálogos sobre Direito Civil-Construindo a Racionalidade Contemporânea. Gustavo Tepedino et alii, Rio de Janeiro: Renovar, 2002, p. 43.

38 JAYME, Recueil des Cours, 251 (1995), p. 60.

39 JAYME, Recueil des Cours, 251 (1995), p. 259: “Dès lors que l'on évoque la communication en droit international privé, le phénomène le plus important est le fait que la solution des conflits de lois émerge comme résultat d'un dialogue entre les sources le plus hétérogènes. Les droit de l'homme, les constitutions, les conventions internationales, les systèmes nationaux: toutes ces sources ne s'excluent pas mutuellement; elles 'parlent' l'une à l'autre. Les juges sont tenus de coordonner ces sources en écoutant ce qu'elles disent."

40 Como ensina SAUPHANOR, p. 31, em direito, a ausência de coerência consiste na constatação de uma antinomia, definida como a existência de uma incompatibilidade entre as diretivas relativas ao mesmo objeto.

41 Veja sobre a aplicação simultânea de várias leis, o CC, o CDC e inclusive as leis administrativas sobre o SFH, duas recentes decisões do STJ. Na bela decisão no Resp. 436.815-DF, Min. Nancy Andrighi, j. 17.12.2002, DJ 28.10.2002, a ementa ensina: "Processual. Civil...Contrato de compra e venda de imóvel e financiamento. SFH. Aplicação do Código de Defesa do Consumidor. empréstimo concedido por associação ao associado. Deve ser afastada a aplicação da cláusula que prevê foro de eleição diverso do domicílio do devedor em contrato de compra e venda de imóvel e financiamento regido pelo Sistema Financeiro da Habitação, quando importar em prejuízo de sua defesa. Há relação de consumo entre o agente financeiro do SFH, que concede empréstimo para aquisição de casa própria, e o mutuário..." E a igualmente bela decisão do Resp. 387.581-RS, Min. Ruy Rosado de Aguiar, j. 21.05.2002, cuja ementa ensina: "Cartão de crédito. Prestação de contas. Mandato. A administradora deve prestar contas sobre o modo pelo qual exerce o mandato que lhe concedeu o usuário para obter financiamento no mercado a fim de financiar as vendas a prazo. Código Civil e Código de Defesa do Consumidor."

42 Veja aplicação simultânea e subsidiária do CDC, como lei geral, face à existência de lei especial sobre prêmios, na jurisprudência do STJ: "Publicidade. Concurso. Prêmio. Numeração ilegível. Código de Defesa do Consumidor...O sistema do CDC, que incide nesșa relação de consumo, não permite à fornecedora - que se beneficia com a publicidade - exonerar-se do 
ria de convenções internacionais e leis modelos) ${ }^{43}$ ou mesmo permitindo uma opção por uma das leis em conflito abstrato. ${ }^{44}$ Uma solução flexível e aberta, de interpenetração ou mesmo a solução mais favorável ao mais fraco da relação (tratamento diferente dos diferentes).

\subsection{Diálogos entre o CC/2002 e o CDC em matéria de comércio eletrônico}

Seguindo os ensinamentos de meu caro mestre alemão Erik Jayme, cabe agora refletir quais seriam os 'diálogos' possíveis entre o Código de Defesa do Consumidor-CDC, como lei anterior, especial e hierarquicamente constitucional (veja mandamento expresso sobre sua criação no sistema jurídico brasileiro, no Art. 48 ADCT/ CF 1988, e como incluído entre os direitos fundamentais, Art. $5^{\circ}$, XXXII da $\mathrm{CF} / 88)^{45}$ e o novo Código Civil, Lei 10.406/2002, que entrou em vigor em janeiro de 2003, como lei posterior, geral e hierarquicamente inferior, mas trazendo algumas normas de ordem pública, que a lei nova mesma considera de aplicação imperativa a contratos novos e antigos (veja art. 2035, parágrafo único da Lei $10.406 /$ 2002).

\subsubsection{Os três tipos de diálogos}

Em minha visão atual, três são os tipos de 'diálogo' possíveis entre estas duas importantíssimas leis da vida privada:

1) na aplicação simultânea das duas leis, uma lei pode servir de base conceitual para a outra (diálogo sistemático de coerência), especialmente se uma lei é geral e a outra especial; se uma é a lei central do sistema ${ }^{46}$ e a outra um

cumprimento da sua promessa apenas porque a numeração que ela mesma imprimiu é defeituosa. A regra do Art. 17 do Dec. 70.951/72 apenas regula a hipóteses em que o defeito tiver sido comprovodamente causado pelo consumidor." (STJ, Resp. 396.943-RJ, Min. Ruy Rosado de aguiar, j. 02.05.2002, DJ 05.08.2002)

43 Veja por exemplo o artigo $1^{\circ}$ do Tratado de Olivos do Mercosul, o qual prevê a opção possível pelo sistema de solução de controvérsias do Mercosur ou de outro fórum international (como a OMC, etc.) e a prevalência da fonte escolhida pelas partes em conflito. Veja ARAÚJO, Nádia. Dispute resolution in Mercosur: The Protocol of Las Leñas and the case law of the Brazilian Supreme Court. Inter-american Law Review, University of Miami, v. 32, nr. 1, p. 25-56, Winter-Spring 2001.

44 Veja sobre o tema a obra de BRIERE. Carine, Les Conflits de Conventions Internationales en Droit Privé. Paris: LGDJ, 2001, em especial, p. 266 e seg.

45 Observe-se que mesmo BRIERE, p. 312 e seg. conclui que há uma hierarquia de convenções, se de direitos humanos, o que se pode transpor para o direito privado como valorando o critério da hierarquia e ainda mais a hierarquia constitucional dos direitos fundamentais, como o direito do consumidor.

46 Veja detalhes in PASQUALOTTO, Adalberto, O Código de Defesa do Consumidor em face do novo Código Civil. Revista Direito do Consumidor, n 43, jul/dez, 2002, p. 106. 
micro-sistema específico, ${ }^{47}$ não-completo materialmente, apenas com completude subjetiva de tutela de um grupo da sociedade. Assim, por exemplo, o que é nulidade, o que é pessoa jurídica, o que é prova, decadência, prescrição e assim por diante, se conceitos não definidos no micro-sistema (como vêm definidos consumidor, fornecedor, serviço e produto nos Art. $2^{\circ} 17,29$ e $3^{\circ}$ do CDC), terão sua definição atualizada pela entrada em vigor do $\mathrm{CC} / 2002$;

2) na aplicação coordenada das duas leis, uma lei pode complementar a aplicação da outra, a depender de seu campo de aplicação no caso concreto (diálogo sistemático de complementariedade e subsidiariedade em antinomias aparentes ou reais), a indicar a aplicação complementar tanto de suas normas quanto de seus princípios, no que couber, no que for necessário ou subsidiariamente. Assim, por exemplo, as cláusulas gerais de uma lei podem encontrar uso subsidiário ou complementar em caso regulado pela outra lei. Subsidiariamente o sistema geral de responsabilidade civil sem culpa ou o sistema geral de decadência podem ser usados para regular aspectos de casos de consumo, se trazem normas mais favoráveis ao consumidor. Este 'diálogo' é exatamente contraposto, ou no sentido contrário da revogação ou abrogação clássicas, em que uma lei era 'superada' e 'retirada' do sistema pela outra. Agora há escolha (pelo legislador, veja Art. 777, ${ }^{48} 721^{49} \mathrm{e}$ $732^{50}$ da Lei $10.406 / 2002$, ou pelo juiz no caso concreto do favor debilis do Art. $7^{\circ}$ do CDC) daquela que vai "complementar" a ratio da outra (veja também art. $729^{51}$ da Lei 10.406/2002 sobre aplicação conjunta das leis comerciais);

3) há o diálogo das influências recíprocas sistemáticas, como no caso de uma possível redefinição do campo de aplicação de uma lei (assim, por exemplo, as definições de consumidor stricto sensu e de consumidor equiparado podem sofrer influências finalísticas do novo Código Civil, uma vez que esta lei nova vem justamente para regular as relações entre iguais, dois iguaisconsumidores ou dois iguais-fornecedores entre si, no caso de dois fornecedores trata-se de relações empresariais típicas, em que o destinatário final fático da coisa ou do fazer comercial é um outro empresário ou comerciante), ou como no caso da possível transposição das conquistas do Richterrecht (Direito dos Juízes) alcançadas em uma lei

47 Veja detalhes sobre o CDC como micro-sistema, in PASQUALOTTO, p. 106 e seg.

48 O texto é o seguinte: "Art. 777. O disposto no presente Capítulo aplica-se, no que couber, aos seguros regidos por leis próprias."

49 O texto é o seguinte: "Art. 721. Aplicam-se ao contrato de agência e distribuição, no que couber, as regras concernentes ao mandato e à comissão e as constantes de lei especial."

50 O texto é o seguinte: "Art. 732. Aos contratos de transporte, em geral, são aplicáveis, quando couber, desde que não contrariem as disposições deste Código, os preceitos constantes da legislação especial e de tratados e convenções internacionais."

51 O texto é o seguinte: "Art. 729. Os preceitos sobre corretagem constantes deste Código não excluem a aplicação de outras normas da legislação especial.” 
para a outra. É a influência do sistema especial no geral e do geral no especial, um diálogo de double sens ${ }^{52}$ (diálogo de coordenação e adaptação sistemática).

Assim, em resumo, haveria o diálogo sistemático de coerência, o diálogo sistemático de complementariedade e subsidiariedade em antinomias e o diálogo de coordenação e adaptação sistemática. Como é impossível neste estudo limitado analisar todos os possíveis 'diálogos' entre todas as normas do Código de Defesa do Consumidor (CDC), e todas as do novo Código Civil de 2002 (CC/2002), restringirei minha análise agora apenas às normas contratuais, e nas normas obrigacionais, mais especificamente àquelas que são consideradas cláusulas abusivas, seja pelo CDC ou pela jurisprudência oriunda do Código de Defesa do Consumidor, até porque alguns já previram a diminuição de efeitos do sistema do CDC, de combate aos abusos com a entrada em vigor das cláusulas gerais do $\mathrm{CC} / 2002 .^{53}$

\subsection{A prevalência da complementariedade ou subsidiariedade do $\mathrm{CC} / 2002$}

Inicialmente, mister frisar que o novo. Código Civil Brasileiro, Lei 10.406 de
10 de janeiro de 2002 (a seguir $\mathrm{CC} /$ 2002), traz ao direito privado brasileiro geral os mesmos princípios já presentes no Código de Defesa do Consumidor (como a função social dos contratos, ${ }^{54}$ a boa-fé objetiva, ${ }^{55}$ etc.). Realmente, a convergência de princípios entre o CDC e o CC/2002 é a base da inexistência principiológica de conflitos possíveis entre estas duas leis que, com igualdade ou equidade, visam a harmonia nas relações, civis em geral e nas de consumo ou especiais. Como ensina a Min. Eliana Calmon: "O Código de Defesa do Consumidor é diploma legislativo que já se amolda aos novos postulados, inscritos como princípios éticos, tais como, boa-fé, lealdade, cooperação, equilíbrio e harmonia das relações." 56

Não haveria, pois, entre estas duas leis possibilidade de conflito de 'princípios', somente de conflitos de 'normas' ou antinomias. Decisivo é, pois, o campo de aplicação de ambas as normas, uma vez que só há conflito de 'normas' quando o campo de aplicação das leis é o mesmo naquele caso concreto. A convergência de campos de aplicação pode levar ao 'conflito', já convergência de princípios é o caminho para o 'diálogo' entre fontes. Mesmo considerando que

52 Veja a obra de SAUPHANOR, p. 32.

53 Veja LOBO, Paulo Luiz Netto. Princípios Sociais dos Contratos no CDC e no novo Código Civil. Revista Direito do Consumidor, vol. 42, abr./jun.2002, p. 195.

54 Assim o texto aprovado: "Art. 421. A liberdade de contratar será exercida em razão e nos limites da função social do contrato".

55 Assim o texto aprovado: "Art. 422. Os contratantes são obrigados a guardar, assim na conclusão do contrato, como em sua execução, os princípios de probidade e boa-fé."

56 CALMON, Eliana. As gerações dos direitos e as novas tendências. Revista Direito do Cosumidor, v. 39, jul./set. 2001, p. 45. 
princípios também são 'normas', ${ }^{57}$ aqui a eficácia maior é sua teleologia ou função no sistema visto como um todo.

A convergência de princípios é vista hoje como um fato bastante positivo para a co-habitação (ou diálogo) das leis novas e antigas no mesmo sistema jurídico. É o que ocorrerá com o CDC e CC/2002. A determinação do campo de aplicação do CDC já foi tema de muitos trabalhos doutrinários e polêmicas e não nos cabe agora repetir. ${ }^{58}$ Mister trabalhar hoje com uma visão plural de um possível campo de aplicação do CDC, revisitado face à entrada em vigor do $\mathrm{CC} / 2002$.

Segundo o $\S 2^{\circ}$ do Art. $2^{\circ}$ da LICC, a lei nova, que estabeleça disposições gerais 'a par das já existentes', como o $\mathrm{CC} / 2002$, 'não revoga nem modifica a lei anterior', no caso, o CDC. Segundo o $\S 1^{\circ}$ do Art. $2^{\circ}$ da LICC, a lei posterior revogará a anterior quando: 1) expressamente o declare; 2 ) regule inteiramente a matéria de que tratava a anterior; 3) seja com ela incompatível. Os dois primeiros casos não parecem ocorrer na prática; nem o CC/2002 revogou expressamente o CDC, nem tratou da relação de consumo, mesmo assim cabe aqui examinar os detalhes desta divergência fundamental entre o campo de aplicação do $\mathrm{CC} / 2002$, como lei geral posterior, e do $\mathrm{CDC}$, como lei especial para regular a relação de consumo.
Subjetivamente, o campo de aplicação do CDC é especial, regulando a relação entre fornecedor e consumidor (Art. $1^{\circ}, 2^{\circ}, 3^{\circ}, 17$ e 29 do CDC) ou relação de consumo (art. $4^{\circ}$ e $5^{\circ}$ do CDC), já o campo de aplicação do CC/2002 é geral, regula toda a relação privada não privilegiada por uma lei especial. Um, o CDC, é um micro-sistema especial, um Código para agentes 'diferentes' da sociedade ou consumidores, em relações entre 'diferentes' (um vulnerável, o consumidor e um expert, o fornecedor). O outro, o CC/2002, é um Código geral, um Código para os iguais, para relações entre iguais, civis e empresariais puras. Logo, não haveria colisão possível entre estas duas leis, como expressamente prevê o Art. $2^{\circ}$ da Lei de Introdução ao Código Civil-.LICC/ 42 , que continua em vigor).

Mister hoje destacar a importância da análise do campo de aplicação subjetivo de uma lei especial. A concentração no, sujeito de direitos é hoje característica de nosso direito privado, é para proteger este sujeito que leis especiais são criadas, micro-sistemas como o CDC, que ajudam a formar o complexo novo sistema do direto privado atual. ${ }^{59} \mathrm{O}$ aplicador da lei deve examinar o conflito com olhos plurais, pois a nova teoria do sujeito é outra: o sujeito está fragmentado e é plural, ${ }^{60}$

57 Veja usando a teoria de Alexy, NEVES, Gustavo Kloh. Os princípios entre a teoria geral do direito e o Direito Civil Constitucional. RAMOS/TEPEDINO, p. 11 e seg.

58 Veja a polêmica entre finalistas e maximalistas, sobre o campo de aplicação subjetivo do CDC e a jurisprudência dos 10 primeiros anos de vigência da lei em meu livro Contratos, $\mathrm{p}$. 252 a 500 .

59 Veja meu livro, Contratos, p. 503.

60 Veja ZIMA, Peter. Theorie des Subjekts, Tübingen: Francke, 2000, p. 216 e seg. 
como o é o grupo dos consumidores. Se a lei é feita para protegê-los, seu campo de aplicação subjetivo não pode ser mais somente 'individual' e sim, necessariamente, também coletivo ou plural. Em outras palavras, quando o CDC assegura um novo direito ao consumidor, no sistema jurídico, este reflete-se de forma plural, com a criação de direitos individuais, individuais homogêneos, coletivos e difusos. Assim atesta a parte processual do CDC (Art. 81 e seg. do CDC), podendo o Ministério Público e os outros legitimados agir no sentido da eficácia destes direitos no mercado brasileiro, valendo-se das normas materiais do CDC.

Sendo assim, mesmo que um direito do consumidor, assegurado por norma do CDC, fosse diametralmente conflitual com uma norma do CC/2002 e o seu campo de aplicação individual fosse o mesmo da nova lei (identidade de campos de aplicação individual), não poderia haver revogação ou retirada da norma especial do sistema, pois seu campo subjetivo coletivo sempre seria maior ou plural. Isto porque o CDC tem uma dimensão coletiva expressa (mesmo sem perder a dimensão individual). O sujeito de direitos que protege é individual, mas também é abstratamente plural, ao mesmo tempo e protegido pelas mesmas normas (todas também de ordem pública, segundo o Art. $1^{\circ}$ do CDC). Já nas normas do CC/2002 prevalece a dimensão individual, pois re- gulamentar o caso privado entre iguais e os direitos dai resultantes é a sua finalidade principal.

Conclui-se que a revogação do CDC pelo CC/2002 como lei geral mais nova não ocorrerá. A lei geral mais nova geralmente preserva as leis especiais e regula expressamente os conflitos e sua hierarquia. Note-se, em primeiro lugar, que o CC/2002, na sua versão aprovada em janeiro de 2001, não possui uma norma de revogação geral tácita, mas sim revoga expressamente o próprio Código Civil de 1917 e parte do Código Comercial de 1850, afirmando apenas: "Art. 2045. Revogam-se a Lei no 3.071, de $1^{\circ}$ de janeiro de 1916 - Código Civil e a Parte Primeira do Código Comercial, Lei ${ }^{\circ}$ 556, de 25 de junho de 1850."

O Art. 2043 preserva apenas as normas penais, processuais e administrativas, indicia a existência de uma revogação tácita, mas revogação somente das leis especiais incorporadas expressamente no texto do CC/2002, afirmando: "Art. 2.043: Até que por outra forma se disciplinem, continuam em vigor as disposições de natureza processual, administrativa ou penal, constantes de leis cujos preceitos de natureza civil hajam sido incorporados a este Código."

Note-se, porém, que o novo Código Civil Brasileiro, ao contrário do Código Civil Alemão, reformado em 2000,61 nada menciona sobre 'consumidores'. Esta expressão constitucional (Art. 170, $\mathrm{V}$ da CF/88) não mencionada em 2.045

61 Veja meu artigo com Ulrich Wehner, "Normas de proteção do consumidor (especialmente, no comércio eletrônico) oriundas da União Européia e o exemplo de sua sistematização no Código Civil Alemão de 1896 - Notícia sobre as profundas modificações no BGB para incluir a figura do consumidor" sobre o tema in $R D C$ vol. 34, p. 50 a 53 . 
normas ${ }^{62}$ do novo CC/2002 (são mencionadas apenas as expressões 'consumo', em seu sentido clássico de destruição, nos Arts. 86, 307, 1290 e 1392, bens 'destinados a consumo', nos Arts. $206 \mathrm{e}$ 592 e crimes 'contra as relações de consumo', no $\S 1^{\circ}$ do Art. 1.011). Sendo assim, podemos concluir, com certeza, que ao CDC não se aplica a norma do Art. 2.043 do $\mathrm{CC} / 2002$. Em outras palavras, podemos concluir que o CDC e o tema de defesa do consumidor não foi "incorporado" ao CC/2002. Ao contrário, é considerado pelo próprio $\mathrm{CC} / 2002$ como um tema a ser regulado por lei 'especial' (como expressamente prevê a Constituição Federal, Art. 48 dos ADCT).

Igualmente, destaque-se que até mesmo as normas sobre função social do contrato (Art. 421), sobre o princípio da boafé (Art. 422) e contratos de adesão (Art. 424) nada mencionam sobre consumidores, pois são normas gerais e genéricas, aplicáveis a contratos civis e comerciais. Daí se retira que as leis especiais (não incorporadas ao CCB/2002) ficaram preservadas e são prevalentes em relação à lei civil geral subsidiária.

Também da história legislativa do projeto podemos retirar esta conclusão. A redação anterior do artigo final do Có- digo (antigo Art. 2040) era mais abrangente e afirmava que ficariam: "revogados o Código Civil e a Parte Primeira do Código Comercial, Lei n ${ }^{\circ} 556$, de 25 de junho de 1850, e toda a legislação civil e mercantil abrangida por este Código, ou com ele incompatível[...]"'(grifo nosso) Mas, como explica o relator, deputado Fiúza, a "boa técnica legislativa" levou a Câmara a determinar quais as leis que o CC/2002 revogaria. ${ }^{63}$

Sendo assim, se a mensagem de 1975 pretendia "incluir na sistemática do Código... a matéria contida em leis especiais promulgadas depois de 1916." ${ }^{64} \mathrm{~A}$ verdade é que, face ao mandamento constitucional de elaborar um Código (Art. $48 \mathrm{ADCT} / \mathrm{CF}$ ), uma lei especial voltada para a defesa só do consumidor, o $\mathrm{CC} / 2002$ restringiu-se a incorporar leis anteriores a 1975, em matéria obrigacional, com algumas adaptações nos anos 90. Conclui-se que os revisores do CC/2002 não tiveram a pretensão de 'incorporar' o CDC ou qualquer norma de proteção específica do consumidor ao Código Civil de 2002. A proteção assegurada é geral, respeitando a lei especial de tutela dos direitos dos consumidores.

O próprio deputado Fiúza, conclui em seu Relatório final que ambas as leis

62 Note-se que o inciso I do Art. 1467 menciona a palavra 'consumidores' como sinônimo de 'fregueses' dos hospedeiros e dos fornecedores de alimentos e pousada ao regular o penhor legal. O texto é o seguinte: “I - os hospedeiros, ou fornecedores de pousada ou alimento, sobre as bagagens, móveis, jóias ou dinheiro que os seus consumidores ou fregueses tiverem consigo nas respectivas casas ou estabelecimentos, pelas despesas ou consumo que aí tiverem feito."

63 Veja BRASIL - Câmara dos Deputados. Relatório final do Relator Deputado Ricardo Fiuza, Código Civil. Brasília, 2000, p. 115.

64 Mensagem nr. 160 de 1975 in TEIXEIRA, Sálvio de Figueiredo. O Novo Código Civil. Belo Horizonte: Del Rey, 2001, p. 322. 
conviverão e que o novo CC/2002 expande para todo o direito privado tendências presentes no próprio CDC, afirmando: "[...]no que tange à disciplina dos contratos, o projeto acompanha a tendência já assente, tanto na jurisprudência como no Código de Defesa do Consumidor, de restringir os efeitos do contrato de adesão, considerando nulas as cláusulas em que o aderente antecipadamente renuncia a direitos resultantes da natureza do negócio, bem como determinando que as cláusulas ambíguas ou contraditórias sejam interpretadas em seu favor." 65

Concluindo, ao comércio eletrônico realizado por consumidores domiciliados no Brasil aplica-se prioritariamente o Código de Defesa do Consumidor e só subsidiariamente, no que couber, o Novo Código Civil (Lei 10.406/2002).

\subsubsection{Diálogo em matéria de direito internacional privado}

A globalização, a aproximação dos mercados, a integração de mercados, a abertura para produtos e serviços estrangeiros, a internacionalidade das relações privadas são, segundo a doutrina atual, os grandes desafios do direito do consumidor. ${ }^{66}$ Segundo as palavras lúcidas de Jean-Michel Arrighi, o consumidor é o "protagonista olvidado". ${ }^{67}$ Tanto nos
Tratados interamericanos, quanto naqueles dedicados à integração, como o Tratado de 1980 da ALADI e o Tratado de Assunção de 1991 do Mercosul, não se encontra a palavra "consumidor" ${ }^{68}$ Também em nenhuma das CIDIPs até hoje assinadas o tema da proteção do consumidor mereceu especial atenção, os temas concentram-se em direito do comércio internacional entre profissionais, em acidentes não oriundos de produtos defeituosos, em proteção de menores, direito de família e sucessões, na parte geral do Direito Internacional Privado e no Processo Civil Internacional. ${ }^{69} \mathrm{Em}$ matéria de comércio eletrônico muitas vezes os contratos são internacionais, daí a importância de assegurar proteção ao consumidor também em Direito Internacional Privado.

\subsubsection{Por um direito internacional privado com conteúdo social}

As relações privadas de consumo assumem hoje também um caráter internacional. Em um mundo de crescentes áreas de complexidade, rapidez e globalização, há um crescimento na importância do Direito Internacional Privado ou dos conflitos de leis no espaço também em relação aos atores leigos deste mercado internacional, ${ }^{70}$ cuja porta de en-

65 Veja BRASIL - Câmara dos Deputados, Relatório final do Relator Deputado Ricardo Fiuza, Código Civil, Brasília, 2000, p. 29.

66 Assim também MACEDO JÚNIOR, p. 45 e 53.

67 ARRIGHI, p. 126.

68 ARRIGHI, p. 126.

69 Veja sobre o tema Carmem TIBÚRCIO, in CASELLA/ARAÚJO, p. 49 e seg.

70 Veja meu artigo, "A insuficiente proteção do consumidor nas normas de Direito Internacional Privado - Da necessidade de uma Convenção Interamericana (CIDIP) sobre a lei apli- 
trada pode ser o simples computador (Televisão, Fax, a tela do Palmtop ou mesmo do telefone celular). ${ }^{71}$ A proteção deste consumidor "eletrônico" de produtos e serviços estrangeiros no Brasil interessa ao Direito do Consumidor. $^{72}$

Segundo ensina KROPHOLLER, ${ }^{73}$ é necessário elaborar normas específicas de DIPr. para a proteção dos consumidores leigos ou não profissionais, pois as conexões hoje existentes para regular o comércio internacional todas têm como base o equilíbrio estrutural de forças ou de interesses profissionais entre os agentes (ambos profissionais) envolvidos, sugerindo como conexões seja a autonomia da vontade (escolha da lei que regerá o contrato pelas partes, no contrato ou após), o local da execução (geralmente o local de execução da prestação característica, sempre prestada pelo profissional em caso de contrato de consumo internacional), ou do local de conclusão do contrato (conectando o contrato com a ordem jurídica do país do ofertante, em contratos à distância, sempre também o ofertante). Este equilíbrio estrutural inexiste nos contratos internacionais concluídos com consumidores leigos.

Segundo bem relembra JAYME, o momento atual é de prevalência de normas materiais em casos internacionais, reduzindo a importância do processo civil internacional tradicional, ${ }^{74}$ tempos de uma maior possibilidade de determinação própria pelo indivíduo (Selbstbestimmung) em direito material, ${ }^{75} \mathrm{de}$ novas técnicas nas Convenções Internacionais tentando harmonizar as diferenças culturais e de desenvolvimento através da cooperação judicial e respeito às normas imperativas locais, ${ }^{76}$ ten-

cável a alguns contratos e relações de consumo", Revista dos Tribunais, São Paulo, v. 90, n. 788, 90, p. 11-56, jun, 2001.

71 Veja também a juíza brasileira MORON, Fernanda (A Internet e o Direito, Revista Consulex, mar. 1997, p. 64): "Como se vê, na medida que as relações que surgem pela Internet transcendem fronteiras, maior necessidade teremos de recorrer a regras do Direito Internacional, ramo jurídico que com certeza apresentará sensível crescimento."

72 Como afirmamos em nosso primeiro artigo sobre o tema, publicado na RT 788/11 e seg: "Consumir de forma internacional é típico de nossa época. O serviço ou produto estrangeiro é status, é bem simbólico na atual cultura de consumo; o turismo, as viagens", a conexão e o "surf" diário na Internet, "o ser consumidor de forma internacional, faz parte da procura pósmoderna dos prazeres, do lazer individual, da realização dos sonhos e do imaginário, é uma distinção social cada vez mais importante." Veja neste sentido, FEATHERSTONE, Mike. Cultura de Consumo e pós-modernismo, Tradução Júlio Assis Simões, São Paulo: Studio Nobel, 1995, p. 31.

73 KROPHOLLER, p. 398 e seg.

74 Assim JAYME, Erik, Zum Jahrtausendwechsel: Das Kollisionsrecht zwischen Postmoderne und Futurismus. In IPRAX-Praxis des Internationalen Privat-und Verfahrensrechts, 2000, p. 169.

75 JAYME, IPRAX 2000, p. 170.

76 Assim JAYME, IPRAX 2000, p. 168. 
tando respeitar os direitos humanos envolvidos no caso, ${ }^{77}$ o que significa, face a revolução tecnológica atual, uma nova prevalência pela residência habitual do consumidor como novo elemento de conexão para determinar a lei aplicável ao comércio eletrônico Business-to-Consumer e novo critério para determinar, a competência do foro. ${ }^{78}$

Mister, pois, superar também no Brasil as conexões tradicionais para proteger o contratante mais fraco. Assim, por exemplo, a regra do favor offerentis, quanto a forma e a conexão na residência do ofertante em contratos entre ausentes, conhecida no direito brasileiro, também são inadequadas para os desafios do comércio com consumidores e sua proteção nos dias de hoje. No caso de contratos ou relações de consumo, o ofertante é sempre o fornecedor (veja Art. 30 Lei 8.078/90 brasileira), mesmo se fictamente denomina-se o contrato de adesão ou as condições gerais contratuais de "proposta" colocada "à acei- tação dos consumidores. Sabe-se que é o fornecedor que redige e determina tal "proposta", logo, tais formulários e a própria publicidade realizada pelo fornecedor ou profissional, determinam que a oferta de consumo seja, hoje, sempre realizada pelo fornecedor. ${ }^{79}$

Esta realidade faz com que as normas brasileiras do Art. $9 \S 2^{\circ}$ da LICC/42 e Art. $9 \S 1^{\circ}$ LICC/42 estejam superadas. ${ }^{80} \mathrm{O} \S 2^{\circ}$ do Art. 9 dispõe que a obrigação resultante do contrato reputa-se constituída no lugar onde residir o proponente, determinando assim a aplicação da lei do lugar de residência do fornecedor para reger os contratos entre ausentes, mesmo os de consumo. Necessário, pois, superar esta regra e escolher, para os contratos de consumo, diferentemente dos contratos internacionais comerciais, uma conexão mais favorável ao consumidor, como a do Art. $5^{\circ}$ da Convenção de Roma de 1980, que dá preferência à lei do país onde o consumidor tem

77 Assim JAYME, IPRAX 2000, p. 171, citando os casos de decisão judicial na Alemanha sobre o desastre de Chernobyl, em que o "local do delito" foi considerado o território alemão onde a "nuvem radiotiva" causou danos, que devem ser indenizados pela empresa russa e, também, os casos sobre comércio eletrônico, em que estão sendo considerados competentes os foros do local de "distribuição" da informação por Internet, logo, do local onde está o consumidor.

78 JAYME, IPRAX 2000, p. 171.

79 No caso brasileiro, o CDC, Lei 8.078/90, determina expressamente que a oferta é sempre do fornecedor ou profissional ex vi lege nos art. 30, 34, 35 e 48. Veja meus comentários, in Contratos, p. 288 e seg.

80 O texto atual da LICC/42 é: “Art. 9. Para qualificar e reger as obrigações, aplicar-se-á a lei do país em que se constituírem. $\S 1^{\circ}$. Destinando-se a obrigação a ser executada no Brasil e dependendo de forma essencial, será esta observada, admitidas as peculiaridades da lei estrangeira quanto aos requisitos extrínsecos do ato. $\$ 2$.A obrigação resultante do contrato reputa-se constituída no lugar onde residir o proponente." 
sua residência habitual como conexão rígida (Art. $5^{\circ} 3$ Conv. de Roma de 1980), se não há expressa manifestação da vontade.

Este mesmo Art. $5^{\circ}$ da Convenção de Roma de $1980^{81}$ determina que a eleição de uma lei para reger o contrato de consumo, isto é, a conexão na autonomia da vontade, não poderá excluir a aplicação das normas e leis imperativas de proteção do país de residência habitual do consumidor, se a) a oferta, publicidade ou algum ato de conclusão do contrato aconteceu neste país (por exemplo, a publicidade para um cruzeiro marítimo organizado na Argentina é feita na televisão aberta ou a cabo brasileira); b) se o fornecedor ou um seu representante receber a reserva ou realizar a contratação no país de residência habitual do consumidor (por exemplo, os contratos de multipropriedade no Uruguai, Punta del Este, com consumidores residentes no Brasil, são celebrados no
Brasil por representantes autônomos, que convidam os consumidores para coquetéis e reuniões, lhe oferecem prêmios e vantagens, onde o empreendimento será explicado e a proposta assinada, assim como o pagamento futuro através de boletos de cartão de crédito que serão assinados também naquelas reuniões de venda em solo brasileiro); c) quando se tratar de venda de produtos e o consumidor viajar para adquirir estes produtos, mas a viagem for organizada pelo fornecedor com esta finalidade de contratação (por exemplo, excursões organizadas para adquirir produtos em uma zona franca ou em uma determinada fábrica no exterior), como esclarece o Art. $5^{\circ}$ da Convenção de Roma de 1980 sobre a lei aplicável às relações obrigacionais oriundas de contratos. ${ }^{82} \mathrm{No}$ caso interamericano, a melhor conexão rígida seria a do domicílio, entendido como residência habitual, a exemplo do Art. $3^{\circ}$ do Protocolo de Santa

810 texto do Artigo é: "Artigo $5^{\circ}$ - Contratos celebrados por consumidores -1 . O presente artigo aplica-se aos contratos que tenham por objecto o fornecimento de bens móveis corpóreos ou de serviços a uma pessoa, o «consumidor», para uma finalidade que pode considerar-se estranha à sua atividade profissional, bem como aos contratos destinados ao financiamento desse fornecimento. 2. Sem prejuízo do disposto no artigo $3^{\circ}$, a escolha pelas partes da lei aplicável não pode ter como consequência privar o consumidor privado da proteção que lhe garantem as disposições imperativas da lei do país em que tenha a sua residência habitual: - se a celebração do contrato tiver sido precedida, nesse país, de uma proposta que lhe foi especialmente dirigida ou de anúncio publicitário, e se o consumidor tiver executado nesse país todos os atos necessários à celebração do contrato, ou se a outra parte ou o respectivo representante tiver recebido o pedido do consumidor nesse país, ou se o contrato consistir numa venda de mercadorias e o consumidor, se tenha deslocado desse país a um outro país e aí tenha feito o pedido, desde que a viagem tenha sido organizada pelo vendedor com o objectivo de incitar o consumidor a comprar.

82 JAYME, Erik; HAUSAMANN, Rainer. Internationales Privat - und Verfahrensrecht. Munique: Beck Verlag, 1998, p. 116. 
Maria (Mercosul) ${ }^{83}$ ou da tradição das CIDIPs $^{84} \mathrm{e}$ suas normas materiais uniformes. ${ }^{85}$

Segundo KROPHOLLER, as normas especiais de proteção dos consumidores, como agentes mais fracos no comércio internacional, deveriam seguir o seguinte método: respeitar a aplicação das normas imperativas (em alemão, Sonderregelung für zwingende Normen) ${ }^{86}$ elaborar normas por tipos contratuais ou temas, ${ }^{87}$ usar normas bilaterais clássicas ${ }^{88}$ optar por elementos de conexão objetivos, e, no caso dos contratos de consumo, optar por outra conexão do que a da prestação característica, ${ }^{89}$ dando preferência a conexões da esfera contratual do mais fraco (Recht der Vertragsphäre des Schwächeren), assim como limitar a autonomia da vontade ou possibilidade de escolha da lei por parte do fornecedor, comerciante ou parte contratual mais forte, ${ }^{90} \mathrm{e}$ impor correções com cláusulas de ordem pública ${ }^{91}$ e cláusula escapatória, ${ }^{92}$ a exemplo da atual lei suíça.

\subsubsection{O CDC como lei de aplicação imediata}

Enquanto não possuímos normas específicas de proteção dos consumidores em matéria de comércio eletrônico

83 ARAÚJO, Nádia, MARQUES, Frederico Magalhães; REIS, Márcio, Código do MercosulTratados e Legislação, Rio de Janeiro: Ed. Renovar, 1998, p. 161.

84 Segundo SIQUEIROS, José Luis, Contribucion de las CIDIP-I, II y III al Desarrollo del Dercho Internacional Privado. In Curso de Derecho Internacional, OEA,1987, p. 170 esta foi uma das grandes contribuições das CIDIPS ao determinar que o domicílio interamericano aproximava-se da figura da residência habitual em voga na Europa, veja também CIDIP-II1979- Convenção sobre o domicílio das pessoas físicas.

85 Como ensina OPPERTI BADAN, Estado Actual del Derecho International Privado en el Sistema Interamericano, IX Curso de Derecho Internacional, Secretaria General, OEA,1983, n. 2.7, a principal inovação da CIDIP-II sobre domićlio das pessoas físicas de 1979 foi a utilização de normas materiais uniformes. Segundo ALMEIDA, Ricardo Ramalho, A convenção Interamericana sobre Domicílio das Pessoas Físicas em Direito Internacional Privado. In: CASELLA, Paulo Borba; ARAUJO, Nádia (Coord.), Integração Jurídica Interamericana: As Convenções Interamericanas de Direito Internacional Privado (CIDIPs) e o Direito Brasileiro, São Paulo: Ltr, 1998, as normas da referida CIDIP-II não são "substanciais", mas sim "qualificadoras", p. 217, ocorre que, na tradição germânica' (veja KROPHOLLER, p. 80, KEGEL, IPR, 35, STEINDORF, Ernst, Sachnormen im internationalen Privatrecht, Vittorio Klostermann, Frankfurt am Main, 1958, p. 30), as normas materiais de ajuda (Hilfsnormen), são consideradas normas materiais de DIPr (materielles Sonderrecht), logo, concordamos com a opinião do mestre uruguaio OPPERTI, Curso OEA, nr. 2.7.

86 KROPHOLLER, p. 648.

87 KROPHOLLER, p. 655.

88 KROPHOLLER, p. 657 e 660.

89 KROPHOLLER, p. 656.

90 KROPHOLLER, p. 656.

91 KROPHOLLER, p. 655.

92 KROPHOLLER, p. 657. 
e o projeto da OAB/SP não for aprovado, parece-me que a jurisprudência seguirá a linha ditada no Resp. 63.981-SP, de considerar todas as normas de ordem pública (interna) do CD como leis de aplicação imediata e, portanto, imperativamente aplicáveis antes das normas de conflito referentes aos contratos internacionais, para a proteção do contratante mais fraco, o consumidor.

O caso de líder em matéria de produtos e serviços estrangeiros e o standard mínimo de proteção dos consumidores tem origem no STJ. Trata-se de um caso envolvendo um turista brasileiro (consumidor ativo), que retorna ao mercado brasileiro. Neste sentido, pode ser usado apenas analogicamente para solucionar os aqui analisados. Nesta decisão de líder, o STJ responsabilizou a filial brasileira pela garantia de produto adquirido nos EUA (distribuído pela matriz no Japão e produzido possivelmente na Indonésia ou China), da marca Panasonic, tudo segundo o Código Brasileiro de Direito do Consumidor, considerado "lei de aplicação imediata".

O Resp. 63.981-SP, cujo relator foi o Min. Sálvio de Figueiredo Teixeira, foi decidido em 4 de maio de 2000 , com a seguinte ementa:

"Direito do consumidor. Filmadora. Defeito da mercadoria. Responsabilidade da empresa nacional da mesma marca (Panasonic). Economia globalizada. Propaganda. Proteção ao consumidor. Peculiaridade da espécie. Situações a ponderar nos casos concretos. Nulidade do acórdão estadual rejeitada, porque suficientemente fundamentado. Recurso conhecido e provido no mérito, por maioria. I - Se a economia globalizada não mais tem fronteiras rígidas e estimula e favorece a livre concorrência, imprescindível que as leis de proteção ao consumidor ganhem maior expressão em sua exegese, na busca do equilíbrio que deve reger as relações jurídicas, dimensionando-se, inclusive, o fator risco, inerente à competitividade do comércio e dos negócios mercantis, sobretudo quando em escala internacional, em que presentes empresas poderosas, multinacionais, com filiais em vários países, sem falar nas vendas hoje efetuadas pelo processo tecnológico da informática e no forte mercado consumidor que representa o nosso país. II - O mercado consumidor, não há como negar, vê-se hoje 'bombardeado' diuturnamente por intensa e hábil propaganda, a induzir à aquisição de produtos, notadamente os sofisticados de procedência estrangeira, levando em linha de conta diversos fatores, dentre os quais, e com relevo, a respeitabilidade da marca. III - Se empresas nacionais se beneficiam de marcas mundialmente conhecidas, incumbe-lhes responder também pelas deficiências dos produtos que anunciam e comercializam, não sendo razoável destinarse ao consumidor as consequiências negativas dos negócios envolvendo objetos defeituosos." ${ }^{93}$

Como se observa, se em caso envolvendo turista brasileiro, cuja única conexão com o Brasil era o domicílio do consumidor, o CDC foi aplicado,

93 DJ 20.11.2000, na íntegra, em sua primeira versão, in RDC 35, p. 270 e seg. 
parece-me provável que o STJ deverá considerar o CDC também "lei de aplicação imediata" em Direito Internacional Privado nos demais casos, em especial nos casos aqui analisados, quando o consumidor passivo contratar no comércio eletrônico, aplicando o CDC, antes do Art. $9^{\circ}$ da LICC/42.

A solução do STJ foi a mesma da União Européia, que considera as Diretivas de proteção do consumidor como "imperativas", ${ }^{94}$ aplicando-as sempre como standards mínimos de proteção dos consumidores europeus, sempre que a lei aplicável é de país fora da zona. Concluindo, em Direito Internacional Privado, no momento, devemos considerar o Código de Defesa do Consumidor como lei de aplicação imediata, a exemplo da decisão do STJ no Resp. 63.981-SP (Rel. Min. Sálvio de Figueiredo Teixeira, j. 04.05.2000).
2 CONTRATOS DE CONSUMO À DISTÂNCIA NO COMÉRCIO ELETRÔNICO E SEU REGIME NO DIREITO MATERIAL BRASILEIRO

\subsection{A especificidade dos contratos à distância no comércio eletrônico realizados por consumidores}

Os contratos "eletrônicos" também são contratos típicos dos atuais tempos pós-modernos. Inspira-me a buscar sua originalidade no regime a abundante doutrina sobre o tema. A doutrina italiana está convencida que estes contratos são "contratos desumanizados" (Oppo) e "sem acordo" (Irti). ${ }^{95}$ Seriam contratos em que o fornecedor não teria mais "rosto", não mais apareceria (ou poderia mesmo não existir) fisicamente ou territorialmente, ${ }^{96}$ pois alguns fornecedores globais são redes de distribuição sem sede fixa. Os contratos à

94 Assim, como conclusão geral, BRÖCKER, Marion. Verbraucherschutz im Europäischen Kollisionsrecht, Frankfurt am Main: Peter Lang, 1998, p. 138 e JUNKER, IPRAX 1998, p. 74.. Também JAYME, IPRAX 1999, p. 412. Assim as Diretivas impõem, por exemplo, a Diretiva 1999/44/CE sobre garantias: "Art. 7. (2) Os Estados membros tomarão as medidas necessárias para que o consumidor não perca a proteção assegurada por esta Diretiva quando o direito de um Estado terceiro é escolhido para regular o contrato, desde que o contrato possua um vínculo estreito com o território de um Estado Parte (da E.U.)" in RDC 38/313.

95 Sobre a controvérsia entre Irti e Oppo, veja FRESNEDA SAIEG, Mónica; HERNÁNDEZ, Carlos A., La Protección del Consumidor en los Contratos a Distancia Celebrados por Medios Informaticos. Revista de responsabilidad civil y seguros (Buenos Aires, La Ley), nr. 5, set./oct., 2001/Hernandez, p. 62-63. A amistosa disputa começou com o instigante artigo de Irti, "Scambi senza acordo" (1998), respondido por Oppo com o artigo "Disumanizzazione del contrato?" (1998) e replica de Irti, "è vero ma... (Replica a Giorgio Oppo)", in Revista di Direitto Civile, anno XLV, nr. 2, 1999, p. 273 e seg.

96 Veja sobre territorialidade e Internet, GROSSFELD, Bernhard. Global Accounting: Where Internet meets Geography, American Journal of Comparative Law, vol. 48, n. 200, p. 261 306. 
distância no comércio eletrônico seriam apenas um subtipo dos contratos "automatizados", contratos realizados diretamente com "computadores" (como os contratos de Home-banking) ou com máquinas de respostas (como os contratos por telefone com respondedores automáticos), contratos "em silêncio" ou "sem diálogo" (expressão de Irti), conduzidos mais pela imagem, pela conduta de apertar um botão, do que pela linguagem. Certo é que nestes contratos há acordo de vontade, há vontade, mesmo que de adesão e "de conduta social típica", logo, há contrato, mesmo que unilateralmente elaborado e muitas vezes não acessível ao consumidor. Há uma bilateralidade essencial, apesar da unilateralidade tão visível. Há bilateralidade de vontades, pois apesar do fornecedor ser "virtual" e do consumidor ser "massificado", apesar do oferecer e do eleger serem mais "automatizados", apesar do direito abstrair mais do plano da validade e considerar mais a confiança despertada, a declaração de oferta realizada, do que a vontade interna do fornecedor, considerar mais a conduta social do consumidor do que a capacidade deste ou de quem atuou por ele ou no seu computador, há um contrato no plano da existência, juridicamente relevante e que produzirá efeitos - e muitos- no plano da eficácia. O contrato final é "velho", o método de contratação é atual, e o meio de contrata- ção - e por vezes de cumprir a prestação imaterial - é que é "novo".

Neste sentido, o novo aqui, parece-me, é a soma de métodos massificados e pósmodernos de contratação. $O$ novo aqui é o fato de - em um revival da obrigação de dar. Novamente a maioria destes contratos do comércio eletrônico envolvem obrigações de dar e não duram no tempo, isto é, são contratos de prestação imediata e pagamento único (com a ajuda do sistema de cartão de crédito), muitos são contratos de compra e venda (por ex: aquisição de livros, CDs, DVDs, ou mesmo a compra de um software/programa/ antivírus, nos chamados contratos informáticos ${ }^{97}$ (pois o produto é enviado pelo meio eletrônico), mas que envolvem "produto imaterial" (o software, por definição legal, as músicas, ebooks, filmes, clips, etc.), em um revival destes contratos frente aos contratos cativos de longa duração, fenômeno antes comentado, que em sua maioria são contratos de serviço e de prestação prolongada no tempo.

O "específico e substancialmente diferente" aqui é o meio eletrônico utilizado, que permite de um lado interatividade, de outro, algo analógico às correspondências ou reembolso postal, no uso de $e$-mail na contratação à distância com intervalo temporal. Também há que se destacar o uso metodológico da imagem, da conduta social típica e do silêncio dos consumidores. Assim, entrando no mundo virtual dos sites (imagens), o caminho é repleto de ima-

97 Como ensina BRIZZIO, Claudia R. La informática en el nuevo derecho, Buenos Aires: Abeledo-Perrot, 2000, p. 34, a expressão informática é uma criação advinda da união de "informação automatizada" e descreve todo o tipo de tratamento de informação por suportes automatizados em computadores. 
gens (e linguagens) e um simples tocar no teclado significa aceitação, um simples continuar um caminho virtual de imagens, sons e de mínimas palavras, significa uma declaração de vontade tácita, um simples continuar no site, em silêncio, abrindo wraps sem protestar ou cortar a conexão, pode significar um determinado tipo de contratação ou declaração negativa ou positiva. Há que se destacar ainda como novo e específico que o meio eletrônico, onde ocorrerá a negociação-virtual e contrataçãovirtual, também modifica os conceitos de tempo real, impondo o tempo virtual, de território, impondo a rede global como "lugar do contrato", em contrato já denominado de desterritorializado, internacional ou nacional, conforme as partes, não conforme o lugar da conclusão do negócio (Art. $9^{\circ}, \S 2^{\circ} \mathrm{da}$ LICC), pois as ofertas nos sites são "globais" em rede e não encontram mais limites territoriais ou nacionais. ${ }^{98}$ Escolho a denominação "contratos do comércio eletrônicos", em homenagem ao livro de Michel Vivant, ${ }^{91}$ obra que tem como finalidade o estudo dos contratos comerciais e de consumo, com a diferença que me concentrarei aqui nos "contratos do comércio eletrônicos" envolvendo consumidores na sociedade brasileira.

\subsection{Os diferentes tipos de contratos à distância no comércio eletrônico realizados por consumidores}

Vivant analisa os seguintes contratos do comércio eletrônico que, por envolverem consumidores, nos interessam: 1 . os contratos de acesso técnico às redes eletrônicas (contrato entre o consumidor e um fornecedor de acesso - servidores, TVs a cabo e outros) ${ }^{100} 2$. o contrato de venda on-line, ${ }^{101}$ venda de produtos materiais, que serão entregues a posteriori no local indicado pelo consumidor e venda de produtos imateriais (software, etc.) a ser enviado pelo mesmo meio eletrônico; 3 . contratos de bens "informacionais", ${ }^{102}$ bens totalmente desmaterializados, como músicas, revistas on-line, educação à distância, acesso a informações, a imagens, filmes, trailers, histórias em quadrinhos, jogos, videogames, etc. Incluiríamos também 4. os contratos de prestação de serviços on-line ou por Internet, como contratação com agências de viagens, transportadoras, seguradoras, bancos e financeiras, contratos não tratados por Vivant.

Nos contratos de acesso dos consumidores (pessoas físicas) à Internet e redes eletrônicas, os temas mais freqüentes de interesse dos consumidores

98 Veja GROSSFELD, Bernhard, Global Accounting: Where Internet meets Geography, in The American Journal of Comparative Law, v. 48, p. 261-306.

99 O autor francês também procura uma certa originalidade nestes contratos, assim afirmando VIVANT, Michel, Les contrats du commerce électronique. Paris: Litec, 1999, p. 4.

100 VIVANAT, p. 13 e seg.

101 VIVANT,p. 89.

102 VIVANT, p. 105 e seg. 
são: as informações sobre os diferentes tipos de planos, a velocidade, qualidade (uso municipal, em deslocamentos, em outros países, webmail, etc.) e quantidade exata da prestação (de horas, grupos, newgroups, e-mails, capacidade de estocagem, etc.), as informações de instalação e uso, assim como para acessar a assistência técnica 24 horas. Os problemas mais freqüentes são as mudanças do conteúdo contratual e do preço, as interrupções do sistema, a demora para acessar, a velocidade esperada não confirmada, o nãobloqueio correto de conteúdos restritos e sites, o envio de e-mails não solicitados, a quebra do sigilo nos endereços eletrônicos e das senhas de acesso, ${ }^{103}$ a não-criptografia estipulada, a falha do web-mail, a não estocagem e a perda de informações, os vírus e cookies, os hackers, a venda casada de equipamentos para rápido acesso, as cláusulas penais, a formação não informada do preço. ${ }^{104}$

Nos contratos de venda on-line e de bens informáticos aos consumidores, os produtos vendidos podem ser materiais, que serão entregues a posteriori no local indicado pelo consumidor e venda de produtos imateriais (software, etc.) ${ }^{105}$ cujo envio é imediato ou retardado no tempo, mas pelo mesmo meio eletrônico. Os problemas mais comuns são a não entrega, ou entrega em endereço errado, as taxas não especificadas de correio ou de recebimento, o retardo na entrega, a falta de sanção pelo retardo na entrega, a falta de garantia para o produto, a impossibilidade de executar o direito de arrependimento (produto aberto, software já enviado, endereço incongruente ou incompleto), a lei aplicável e a jurisdição competente, por vezes até uma jurisdição arbitral virtual compulsória, a venda casada, a recusa de venda, a falha na segurança com os dados do consumidor, dados privados e dados sensíveis, como o seu número de cartão de crédito, a falha na cobrança no cartão de crédito (cobrança a mais, cobrança antes da entrega, etc.), as diferenças entre as fotografias do site e os produtos recebi-

103 Veja decisão recente do TJ-RS sobre o tema, em que o provedor mesmo entra com ação contra usuário comercial seu que quebrou indevidamente as senhas e endereços dos outros usuários para enviar publicidade comercial: "Ação ordinária de obrigação de não fazer, cumulada com tutela antecipada e pedido cominatório. Provedor de Internet. Acesso indevido a Banco de Dados da Provedora por parte de usuário. Ônus da Prova... impunha-se a procedência da ação. Hipótese em que os réus violaram o sigilo de usuários de provedor da Internet em notória ofensa à garantia constitucional insculpida no art. $5^{\circ}$, XII, da Carta Federal. Apelação desprovida" (TJ/RS, Ap.C 70001918333, j. 08.05.2001, Des. Fernando Braf Henning Júnior).

104 Veja VIVANT, p. 17, 18 e 19. Como alerta FÉRAL-SCHUHL, Christiane, Cyber DroitLe droit à l'épreuve de l'Internet, 2. Paris: Dalloz-Dunod, 2000, p. 171, estes contratos de acesso à Internet são tão conflituais que o governo francês interveio para impor informações mínimas e proibir certas práticas comerciais. Veja no Brasil, trabalho pioneiro de Antonio Joaquim Fernandes.

105 Veja VIVANT, p. 89 e seg. 
dos, a compra involuntária ao apertar o ícone, o erro não sanável na contratação, etc.

Nos contratos de bens "informacionais", ${ }^{106}$ bens totalmente desmaterializados, como músicas, ebooks, revistas on-line, acesso a informações e bancos de dados, a imagens, filmes, trailers, histórias em quadrinhos, jogos, videogames, etc., os problemas mais comuns - além dos outros anteriormente mencionados - seriam as próprias condições de uso do bem transmitido (cópia, download, etc.), a garantia de prestabilidade dada, os erros na contratação e o direito de arrependimento, a desatualização ou imprecisões dos bancos de dados, a demora na prestação das informações, do lazer, etc. ${ }^{107} \mathrm{Um}$ regime especial, com responsabilidade qualificada dos fornecedores, é o dos contratos por Internet visando conselhos, aconselhamento (financeiro, na compra de produtos complexos ou em atividade, como corretor), pareceres (econômicos, estatísticos, advocatícios, etc.) ${ }^{108}$ tratamentos (medicinais, psicológicos, médicos, etc.). ${ }^{109}$ Os contratos envolvendo educação à distância através da Internet também envolvem questões específicas, geralmente reguladas em leis especiais, envolvendo garantias, reconhecimento dos diplomas, títulos, qualidade e quantidade da informação, direitos autorais, modos de cobrança e proibindo certas práticas comerciais nestes contratos educacionais. ${ }^{110}$ Também mencione-se que os contratos envolvendo jogos de azar, prêmios, práticas comerciais proibidas em alguns países (venda em bola de neve, etc.) e lazer com conteúdos adultos ou pornográficos, envolvem a aplicação de normas de ordem pública e proibições específicas de cada país envolvido. ${ }^{\prime \prime}$

Nos contratos de prestação de serviços on-line ou por Internet, como contratação com agências de viagens, transportadoras, seguradoras, ${ }^{112}$ bancos e fi-

106 VIVANT, p. 105 e seg.

107 Como alerta SCHMITZ, Dirk. Die Vertraglichen Pflichten und die Haftung der Informationsanbieter im Internet, Stuttgart: Kolhammer, 2000, p. 131 e seg., se as informações e dados são gratuitos na Internet e realmente não remunerados indiretamente, o regime é diferenciado, análogo às doações e liberalidades do direito civil geral, mas com um regime sui generis de responsabilidade civil (p.142).

108 Sobre o tema da prestação de serviços advocatícios pela Internet, veja artigo específico de Maria Cristina Zucchi, in DELUCCA, Newton; SIMÃO, Adalberto. Direito e Internet: Aspectos Jurídicos Relevantes. São Paulo: Edipro, 2000, p. 329 a 350.

109 Assim alerta SCHMITZ, p. 135 e seg.

110 Assim alerta REICH/NORDAUSEN, p. 64 e seg.

111 Sobre o tema veja WIMMER, Norbert; GERHARD, Michael, Der Online-Provider im neunen Multimediarecht, Baden-Baden: Nomos, 1998, Michael, p. 40 e seg.

112 Sobre seguros-online, veja WINTER, Gerrit. "Internationale Online-Versicherungs als Korrespondenzsversicherung", in Versicherungsrecht 2001, p. 1461 e seg. 
nanceiras, ${ }^{113}$ os problemas mais comuns são os relacionados à qualidade, quantidade, tempo e modo da prestação do serviço, e a segurança deste, em especial, tratando-se de home-banking, financiamento on line ou por automáticos bancários. ${ }^{114}$ Interessante observar que neste tipo de contratação, aplicase o direito de arrependimento e reflexão (Art. 49 do CDC). Assim resultaria, também no Brasil, se uma empresa aérea vende em seu site um bilhete ou faz um financiamento para o cliente, há direito de arrependimento do consumidor-leigo, ${ }^{115}$ da mesma forma, se o consumidor faz um leasing ou aluga um automóvel, ${ }^{116}$ ou mesmo faz um empréstimo/mútuo on-line no seu homebanking. ${ }^{117}$ Segundo Meents, problemático é apenas o arrependimento em matéria de fornecimento de informações mensais ou revistas. Nestes casos, usam os doutrinadores europeus uma analogia ao fornecimento de crédito mês a mês e o direito de arrependimento renova-se, sempre que um novo mês inicia. ${ }^{118}$

Santos e Rossi classificaram estes contratos do comércio eletrônico com execução no ambiente virtual de "comércio eletrônico direto", lembrando ainda que o pagamento se faz geralmente mediante o uso de cartões de crédito ou Eletronic Fund Transfer-EFT, reforçando a natureza intangível do objeto contratual e sua execução. ${ }^{119}$

Cesar Santolim, em sua pioneira obra, 1985, classificou os contratos "por computador", em três tipos: aquele que usa o computador como "simples meio de comunicação", e se assemelha na disciplina aos contratos por carta, correspondência comercial, à distância típicos; aquele que usa o computador "como local de encontro de vontades já aperfeiçoadas", e aquele em que o computador é "auxiliar no processo de formação da vontade

113 Como esclarece SPINDLER, Gerald (Org.). Vertragsrecht der Internet-Provider. Colonia, 2000, p. 341, somente os contratos bancários com consumidores e de investimento receberam um tratamento especial na Diretiva européia 200/31/CE (Art. 3,IV), face a especial vulnerabilidade dos consumidores, aplicando-se suas normas imperativas, quebrando o princípio da lei do país de origem (Herkunftslandprinzip).

114 Veja TIMM, Lucianno Benetti. A Prestação de Serviços Bancários via Internet (home banking) e a proteção do consumidor. Revista de Direito do Consumidor, v. 38, 2001, Home banking, p. 74 e seg. e meu artigo "Sociedade de informação", p. 49 e seg. A análise clássica é de GAVALDA, p. 225 e seg.

115 Este direito é comum na Europa, veja MEENTS, Jan Geert. Verbraucherschutz bei Rechtsgeschäften im Internet. Colônia: Otto Schmidt, 1998, p. 31.

$116 \mathrm{O}$ direito de arrependimento em matéria de leasing também existe na Europa, nestes casos, veja MEENTS, p. 32.

117 Este direito de arrependimento existe também na Europa, veja MEENTS, p. 245 e seg.

118 Assim ensina MEENTS, p. 38, 40 e 41.

119 SANTOS e ROSSI, p. 115. 
(Contratos por computador stricto sensu)". 120

Santos e Rossi destacam que as contratações neste espaço eletrônico podem ser interpessoais, interativas e intersistêmicas, ${ }^{121}$ as duas primeiras podem ser de consumo e interessam-nos em especial, já as intersistêmicas, com sistemas aplicativos previamente programados pelos fornecedores, são típicas de contratos entre comerciantes e com finalidade comercial. ${ }^{122}$

Já os recentes estudos de matéria tributária e da $\mathrm{OECD}^{123}$ afirmam que as transações por meio eletrônico com consumidores e que interessam a este estudo podem ser as seguintes: tratamento eletrônico de encomendas de produtos materiais; pedido eletrônico e download de produtos digitais; pedido eletrônico de atualizações e itens adicionais; pedido de software ou outro produto digital para usuário único; manutenção de sotfware; armazenagem de dados, suporte ao usuário, sistema de pesquisa e recuperação de dados; fornecimento de dados exclusivos ou outros dados com forte valor agregado, acesso eletrônico a assessoria profissional; informações técnicas, entrega de informações; acesso a um web interati- vo; acesso a um portal de compras online, acesso a leilões on-line; sites com ofertas de produtos em anexo, transmissão de dados contínuos (em tempo real) através da web; provedores de acesso à Internet.

\subsection{Os diferentes elementos dos contratos à distância do comércio eletrônico de consumo}

Como se observa o chamado "comércio eletrônico" é realizado através de contratações à distância, por meios eletrônicos (e-mail, etc.), por Internet (on line) ou por meios de telecomunicações de massa (telemarketing, TV, TV a cabo, etc.), é um fenômeno plúrimo, multifacetado e complexo, nacional e internacional, onde há realmente uma certa "desumanização do contrato" ("disumanizzazione del contratto").124 A expressão escolhida pela doutrina italiana choca, é esta sua principal finalidade. Assim como Ghersi denominava de "contrato sem sujeito" o primeiro tipo de contrato pós-moderno, aqui temos um outro tipo de contrato pós-moderno, em que a impessoalidade é elevada a graus antes desconhecidos e no qual todas as técnicas de contratação

120 SANTOLIM, p. 24 e 25.

121 SANTOS e ROSSI, p. 111.

\section{Assim SANTOS e ROSSI, p. 112.}

123 A sistematização a seguir foi realizada por Atílio Dengo, advogado da "portoweb", com base nos estudos da OECD, da qual foram retiradas somente as transações que, na visão da autora, são de consumo. Veja DENGO, Atílio, Tributação do Comércio Eletrônico. Dissertação de Mestrado da Faculdade de Direito do Rio Grande do Sul, Porto Alegre: 2001, p. 206 a 254. 124 Assim a expressão de OPPO, p. 525, citando Natalino Irti e sua expressão "scambi senza accordo". 
de massa se reunirão: do contrato de adesão, das condições gerais contratuais ao marketing agressivo, à catividade do cliente, à internacionalidade intrínseca de muitas relações, à distância entre o fornecedor e o consumidor. Se temos aqui presentes os elementos da contratação massificada e geral, da pressão e da distância, fenômenos já conhecidos, por exemplo, com a venda por correspondência, por catálogo e outras, somente uma descrição mais detalhada do iter da "contratação no comércio eletrônico" pode esclarecer como este "meio"/"instrumento" de contratação pode ser tão especial, a ponto de criar um fenômeno próprio e diferente de seus predecessores.

O fenômeno é novo por sua fluidez, complexidade, distância, simultaneidade ou atemporalidade, desterritorialidade e objetividade ou autonomia. Vejamos, a contratação é à distância, e esta distância televisiva ou telemática traz uma nova espécie de pressão (Zwang). Não a pressão do vendedor em sua porta, mas do fato da oferta estar dentro de sua casa, no seu trabalho, no seu espaço privado, nas suas férias, atemporalmente, dia e noite, em todos os lugares do mundo, onde a oferta negocial puder ser acessada ou vista. A distância física entre o fornecedor e o consumidor é enorme fator de debilidade informativa, as informações disponíveis são aquelas escolhidas pelo fornecedor e acessadas com uniformidade. A distância física entre o fornecedor e o consu- midor é fator de insegurança, tanto quanto ao efetivo envio do produto (por exemplo: livros, CDs, DVDs, automóveis, eletrodomésticos, software, peças de um leilão eletrônico, etc.), ou serviço (informações, filmes, músicas acesso à Internet, etc.), à lisura da forma de pagamento e do relacionamento póscontratual (débito no cartão de crédito, clonagem de cartões de crédito, acesso a dados privados, garantias do pós-venda, etc.), quanto em relação à lei aplicável ao contrato, uma vez que muitos destes fornecedores "eletrônicos" localizam-se no exterior.

A fluidez ou desmaterialização da contratação é um elemento a ser considerado: o fornecedor não aparece materializado através de um vendedor, o fornecedor não tem mais "cara", tem sim uma marca, um nome comercial, uma determinada imagem, um marketing virtual ou televisivo, uma estratégia de telemarketing. $\mathrm{O}$ fornecedor não tem endereço comprovável, mas apenas 'informável'. Do fornecedor não se sabe sequer se é realmente um profissional, pois dada a diminuição dos custos de oferta e transação que a Internet traz, ${ }^{125}$ o fornecedor pode ser um "iniciante" ou mesmo um adolescente "genial", o fornecedor pode ser, em resumo, um outro consumidor, como no caso dos leilões por Rede ou dos negócios eventualmente realizados em chats ou salas virtuais.

Outro elemento a considerar-se é a complexidade técnica e jurídica deste 
tipo de contratação à distância. Para lá do click-agreement, que seria contratado com um simples bater de uma tecla no lugar indicado, o comércio eletrônico é pleno de surpresas, desde os contratos "encapsulados" o wraps-agreements, que só são visualizados após a contratação, contratos por série de clicks em cadeia, aos cookies, presentes desvendadores dos visitantes de determinado site ou portal, aos contratos que só são virtuais e nunca podem ser realmente "captados" e perenizados pelo consumidor, tendendo - ou facilitando - a que o fornecedor mude o conteúdo contratual com o passar do tempo virtual. ${ }^{126}$

Quanto à complexidade jurídica, mister frisar que todos os contratos não solenes podem ser hoje realizados por $e$ mail, on-line, por telefone, cabo ou por Internet. Em especial as contratações bancárias, as envolvendo financiamento, crédito e renegociação de dívidas, devem receber especial atenção. ${ }^{127}$ Tratase do mais novo efeito da sociedade de informação ${ }^{128} \mathrm{em}$ matéria bancária. Nos últimos dez anos, o mercado brasileiro de serviços financeiros modificou-se drasticamente. ${ }^{129}$ Verifica-se um aumento substancial no uso de cartões de crédito, cartões eletrônicos, atendimento bancário à distância, via telefone ou Internet, e no número geral de clientes bancários. Da mesma forma, ocorreu também, por parte do governo brasileiro, uma forte desregulamentação e privatização do sistema financeiro e creditício, aumentando assim a competição entre instituições financeiras, no mesmo momento em que a defesa do consumidor foi finalmente regulada através do Código de Defesa do Consumidor (Lei 8.078/90). Há também o chamado Código do cliente bancário, a Res. 002878 do Bacen, que "dispõe sobre procedimentos a serem observados pelas instituições financeiras e demais instituições autorizadas a funcionar pelo Banco Central do Brasil na contratação de operações e na prestação de serviços aos clientes e ao público em geral."

Lorenzetti, em interessante resumo, ${ }^{130}$ destaca, como elementos novos e conjuntos deste fenômeno a distância entre

126 Veja LORENZETTI, Comercio eletrónico, p. 202

127 Veja sobre o tema meu artigo "Sociedade de informação e serviços bancários" e in TIMM, Lucianno Benetti, A prestação de serviços bancários via Internet (Home banking) e a proteção do consumidor, Revista de Direito do Consumidor, v. 38, 2001, p.79 e seg.

128 Sobre sociedade de informação, veja CASTELLS, Manuel, End of Millennium (The Information Age: Economy, Society and culture, volume III), Blackwell P., Oxford, 1998, p. 1, que assim a comenta: "...this is indeed a time of change... a technological revolution, centered around information, has transformed the way we think, we produce, we consume, we trade, we manage, we commu nicate, we live, we die, we make war, and we make love. A dynamic global economy has been constituted around the planet, linking up valuable people and activities from all over world, while switching off from the networks of power and wealth, people and territories dubbed as irrelevant from the perspective of dominant interests..."

129 Cf. MARQUES,Cláudia Lima. Les contrats de crédit dans la législation brésilienne de protection du consommateur. Consumer Law in the Global Economy. Ashgate-Dartmouth, Aldershot, England: 1997, p. 321-348.

130 LORENZETTI, Comercio eletrónico, p. 163 e seg. 
fornecedor e consumidor, a simultaneidade ou atemporalidade da oferta e da aceitação, assim como da contratação em si, a desterritorialidade da contratação, realizada em "território" virtual, no écran do consumidor, mas em realidade de execução à distância e a objetividade ou autonomia das duas vontades exteriorizadas, seja frente a uma máquina, no fax, no telefone ou em qualquer outro meio virtual.

\subsubsection{Formação do vínculo e disciplina material destes contratos}

Inicialmente, mister frisar que a disciplina destes contratos à distância no comércio eletrônico é a mesma que a dos outros contratos à distância, estando regulados no CDC. Necessário é, porém, destacar a vulnerabilidade especial do consumidor quando se utiliza do meio eletrônico. Em outras palavras, o meio eletrônico, automatizado e telemático, em si, usado profissionalmente pelos fornecedores para ali oferecerem seus produtos e serviços aos consumidores, representa aos consumidores leigos, um desafio extra ou vulnerabilidade técnica. O consumidor não é - mesmo que se considere - um especialista ou técnico em computadores e na Internet.

Esta "falha tecnológica" é geral, mas não desanima, ao contrário, fascina a maioria. É típica da pós-modernidade. Apesar desta "falha tecnológica" ou vulnerabilidade frente ao meio virtual, milhares de consumidores, sem medo, negociam, compram e participam até mes- mo de leilões e outros "divertimentos" consumistas sem censura, através da rede mundial da Internet. Atuam eles sem conhecimento técnico, sem fronteiras, sem território, sem passado, sem experiência e com uma fluida confiança, justamente no Direito "do Consumidor", e em uma vaga (e muitas vezes inexistente) proteção "internacional" dos mais fracos, confiando nas respostas pelo menos razoáveis que a Justiça dará. É um contexto novo de superficialidade, hedonismo consumista e insegurança pós-moderna.

\subsubsection{Proteção quando da formação} do vínculo à distância no comércio eletrônico de consumo

Efetivamente, estes muitos consumidores que hoje negociam neste mundo de consumo eletrônico necessitam de uma proteção, e os aplicadores do Direito devem conhecer e dominar as linhas básicas que regem estas e outras negociações de consumo, sejam nacionais ou internacionais. Proteger e melhorar a posição jurídica contratual deste negociador mais fraco e leigo no comércio eletrônico, que é o consumidor pessoa física residente no Brasil, parece ser a finalidade maior da doutrina brasileira e dos projetos de leis existentes sobre o assunto. Como ensinam Lorenzetti e o advogado da Microsoft, parece haver consenso universal de que o consumidor no comércio eletrônico deve receber o mesmo grau de proteção que já alcançou em seu país no comércio normal. ${ }^{131}$ 
Como destaca o professor alemão Norbert Reich, ${ }^{132}$ existem pelo menos cinco diferentes constelações de procedimentos para que esta contratação à distância no comércio eletrônico com consumidor se realize: a) ou o consumidor se dirige a um fornecedor conhecido (rede de lojas de eletrodomésticos, de roupas, fabricante de carros, marcas famosas, etc.) por meio eletrônico; b) ou o consumidor encontra a publicidade no site do fornecedor, quando está surfando na Internet e se interessa pela oferta; c) ou a publicidade enviada por e-mail leva o consumidor virtual ao sítio de Internet do fornecedor; e) ou a publicidade enviada por $e$-mail já contém o link fornecedor que o consumidor então acessa.

Quanto à da formação do contrato, a doutrina ${ }^{133}$ destaca os vários (e diferenciados) momentos da fase pré-contratual, que interessam ao direito do consumidor, a começar pela oferta ou propos- ta pública, que representam os antes mencionados sites, links, e-mails, a publicidade, os spams e outras manifestações virtuais de 'vontade negocial' dos fornecedores do mundo inteiro. ${ }^{134} \mathrm{Con}$ siderando que estas manifestações de vontade negocial dos fornecedores contêm os elementos da oferta e despertam a confiança dos consumidores, são mais do que simples "convites públicos à oferta". Segundo parece-me ser a primeira qualificação pela lex fori (lei brasileira), serão consideradas ofertas, no sentido do Art. 30 do CDC (e, parece-me, também serão consideradas propostas, no sentido do Art. 429 do Código Civil de 2002, se comerciais e puramente civis). ${ }^{135}$

As conclusões do V Congresso Brasileiro de Direito do Consumidor, de Belo Horizonte, em 2000, já foram pela auto-aplicação das normas de direito do consumidor brasileiras ao comércio eletrônico com consumidores. ${ }^{136} \mathrm{E}$ consi-

citando o Joint statement on eletronic Commerce da Austrália e do Japão, as recomendações da OECD, as regras da união européia, as quais poderíamos unir os esforços da UNCITRAL, UNIDROIT e da Conferência de Haia.

132 REICH/NORDHAUSEN, p. 4.

133 Veja, por todos, LORENZETTI. Comércio eletrônico, p. 175 e seg.

134 Veja, por exemplo, a decisão do Tribunal de Hamburgo (OLG Hamburg), de 22.02.2001, que considerou que um link só pode ser incluído em um site, se for esta a vontade negocial do conectado, veja NJW-RR, 2001, p. 1198. Também é considerando qualquer publicidade online vontade negocial e o lugar onde despertar a confiança como conexão, veja LANDFERMANN, Hans-Georg. Internet-Werbung und IPR, in Festchrift für das 75 Jahre Max-PlankInstitut Hamburg, Baden-Baden: Nomos, p. 514.

135 Considero que o Código Civil de 2002 não rege as relações de consumo, senão subsidiariamente e como base conceitual, neste sentido o Art. 429 do $\mathrm{CCBr} / 2002$ regularia as relações inter-empresárias (B2B) e as puramente civis (se assim consideradas as realizadas por dois 'consumidores-leigos' pela Internet, C2C). De qualquer maneira, vale a menção do referido novo Artigo: "Art. 429. A oferta ao público equivale a proposta quando encerra os requisitos essenciais ao contrato, salvo se o contrário resultar das circunstâncias ou dos usos. Parágrafo único. Pode revogar-se a oferta pela mesma via de sua divulgação, desde que ressalvada esta faculdade na oferta realizada."

136 As conclusões, publicadas in Revista de Direito do Consumidor, vol. 35, p. 265, foram: "10.A argumentação em favor da aplicação da lei de domínio do fornecedor é inadequada, 
derando que qualquer consumidor residente no Brasil pode aceitar qualquer oferta do fornecedor, nacional ou estrangeiro, concluíram pela caracterização destas práticas negociais como oferta de consumo. ${ }^{137}$

A preocupação da doutrina é "jurisdicizar" estas práticas comerciais visando o comércio em todo o globo de seus produtos e limitar a revogabilidade desta oferta, que desperta a confiança dos consumidores. Concorde-se com Lorenzetti, quando afirma que a prática negocial de ofertar produtos e serviços pela Internet, em seus diversos modos, interativos e estáticos, é oferta de consumo, que pode ser aceita pelo consumidor a qualquer momento, nas condições da oferta realizada. ${ }^{138} \mathrm{~A}$ revogabilidade vai depender da lei aplicável ao caso, mas se sugere ao fornecedor já informar as condições da oferta na publicidade, site ou meio eletrônico usa- do para tal. Aqui ganham em importância os usos e costumes do meio, pois que as ofertas de fornecedores internacionais geralmente são em línguas estrangeiras (o que já ajuda a formação da confiança do consumidor brasileiro de que está celebrando um contrato internacional), os prazos de reflexão variam conforme as legislações e usos locais e podem ser mais favoráveis ao consumidor brasileiro, servindo a lei brasileira como lei imperativa de uso subsidiário, se mais favorável ao consumidor aqui residente. A forma de perenizar a oferta também é diferente, pois, uma vez não aceita na forma usual (click, informação de certos dados, etc.), a oferta pode ser retirada do site sem que o consumidor nada possa fazer, se não a aceitou devidamente, segundo os usos e condições gerais do fornecedor. Como se verifica, aqui o meio vir-

pois parte do pressuposto que a proteção e tutela do consumidor, através da lei de seu domicílio, seria um entrave ao progresso da economia, desenvolvimento e o progresso econômico, por imposição constitucional, devem ter por paradigma a defesa do consumidor. (aprovada por unanimidade)" e "11. As normas do CDC, como expressamente consignado em seu artigo $1^{\circ}$, são de "ordem pública e de interesse social", entre a ordem pública local e a ordem pública estrangeira o juiz deve preferir a ordem pública de seu país; as disposições do CDC, por serem normas de ordem pública, não podem deixar de ser aplicadas às relações de consumo que envolvem consumidores residentes no território nacional, ressalvada a aplicação cumulativa da legislação estrangeira mais favorável. (aprovada por unanimidade)"

137 As conclusões do painel foram "A prática do comércio eletrônico não prescinde de prévia autorização do ofertante para o dispor de seus produtos e serviços pela Internet. Isto não significa que o mesmo esteja a margem dos pré-requisitos legais determinados para a prática de atos de comércio. (aprovada por unanimidade)", "No momento em que a oferta suficientemente precisa foi veiculada pela rede mundial denominada Internet, está o fornecedor a ela vinculado; não cabe a retratação do direito civil; é necessária a ciência do fornecedor da aderência do consumidor à sua proposta, ou mesmo da declaração do consumidor ter aceitado a oferta, por se tratar de declaração unilateral de vontade do fornecedor, da qual exsurge obrigação perfeita, ipso facto, exigível. (aprovada por unanimidade) e "A oferta suficientemente precisa veiculada pelo fornecedor, através da Internet, implica, via de regra, contrato de adesão concluído com aderência virtual do consumidor, haja vista que o conteúdo contratual foi pré-elaborado de maneira abstrata, genérica, rígida e uniforme. (aprovada por unanimidade).

138 LORENZETTI. Comércio eletrônico, p. 187. 
tual, sua instantaneidade e interatividade, influencia o regime da oferta e aceitação.

Seja considerado oferta de consumo ou não, há que se considerar que estas práticas comerciais dos fornecedores fazem nascer deveres de boa-fé geral, como o de informação, identificação do ofertante, identificação de oferta comercial, cuidado com os dados do consumidor (dever de preservação da privacidade do consumidor, ${ }^{139}$ de proteger contra invasões no site ou na rede) ${ }^{140}$ e deveres de boa-fé específicos do meio virtual, como o de confirmação individual, de perenização da oferta e do contrato e deveres de cooperação na comunicação (o silêncio do fornecedor pode ser usual no comércio, mas é fonte de insegurança e quebra da confiança frente ao consumidor), ${ }^{141}$ na execução à distância (geralmente por correio e outros meios de execução da prestação característica, que é a do fornecedor) e no pagamento à distância (cuidados ao retirar a quantia do cartão de crédito, com o número do cartão de crédito, etc.), somados a cuidados específicos aos perigos do meio virtual (criptografia, combate aos hackers, arquivação múltipla para evitar perdas, etc.). Nestes deveres específicos de uma boa-fé atualizada às práticas (e perigos) do meio eletrônico ou virtual, destaque-se o dever de possibilitar ao consumidor "perenizar" a informação ou dado eletrônico, a evitar que a confiança despertada por uma oferta, publicidade ou contrato, seja frustrada com a mudança no tempo (imediata, muito fácil e sem custos no mundo virtual) das "regras do jogo", da oferta, do leilão, do contrato, etc.

Os deveres de informação, de confirmação e de cuidado dos fornecedores do comércio eletrônico são preocupações de todos os projetos de lei, do direito comparado e da doutrina. ${ }^{142}$ Em resumo, deve o fornecedor informar sobre o meio usado, sobre o produto ou serviço que oferece, sobre as suas condições gerais contratuais e condições específicas da oferta e deve se identificar de forma clara e eficaz. ${ }^{143} \mathrm{O}$ projeto da OAB/SP, dispõe: "Art. $4^{\circ}$ - A oferta de contratação eletrônica deve conter claras e inequí-

139 Sobre o tema, veja artigo específico de PODESTÁ, in DeLucca/Internet, p. 155 e seg. 140 Sobre o tema, veja artigo específico de SIMÃO FILHO, in DeLucca/Internet, p. 101 e seg. 141 No direito geral, tanto o Art. 1084 do CCBr.CCB/16, quanto o Art. 11 do CCBr.CCB/2002 dispõem que: "Art. 111. O silêncio importa anuência, quando as circunstâncias ou os usos o autorizarem e não for necessária a declaração de vontade expressa." Neste sentido, afirmo no texto que, no mundo virtual, o silêncio não significa aceitação dos consumidores e sim, abuso comercial, a violar a confiança dos consumidores frente aos profissionais, os fornecedores do comércio eletrônico. A vontade do consumidor pode ser expressa por palavras ou atos (clicks, condutas sociais típicas, etc.), mas não presumida do silêncio. Veja nesse sentido decisão do Tribunal de Colônia (Köln), de 04.09.1998, in VuR 1999, p. 69-71, que considerou abusiva a nova prática dos fornecedores cobrarem taxas de ligação para um consumidor que estava recebendo uma ligação publicitária, apesar de seu silêncio. Com opinião contrária, BARBAGALO, Erica Brandini. Contratos eletrônicos, Saraiva, São Paulo, 2001, p. 20.

142 Veja, por todos, em síntese de Direito Comparado perfeita, LORENZETTI. Comércio eletrônico, p. 188 a 190.

143 Veja LORENZETTI. Comércio eletrônico, p. 188. 
vocas informações sobre: a) nome do ofertante e o número de sua inscrição no cadastro geral do Ministério da Fazenda, e ainda, em se tratando de serviço sujeito a regime de profissão regulamentada, o número de inscrição no órgão fiscalizador ou regulamentador; b) endereço físico do estabelecimento; c) identificação e endereço físico do armazenador; d) meio pelo qual é possível contatar o ofertante, inclusive correio eletrônico; e) o arquivamento do contrato eletrônico pelo ofertante; f) instruções para arquivamento do contrato eletrônico pelo aceitante, bem como para sua recuperação, em caso de necessidade; e g) os sistemas de segurança em- pregados na operação." ${ }^{144} \mathrm{O}$ projeto, muito corretamente, impõe uma série de deveres de boa-fé ao fornecedor: limitava as informações que o fornecedor podia requerer do consumidor, ${ }^{145}$ impõe o dever de identificar a mensagem como oferta comercial, ${ }^{146}$ dever de confirmar a aceitação por meio automático para o consumidor, ${ }^{147}$ dever de cuidado de criar um ambiente seguro para a contratação eletrônica, ${ }^{148}$ e um dever de perenização das informações enviadas, ${ }^{149}$ mas traz polêmicas normas especiais para consumidores e normas processuais. ${ }^{150}$ Ainda não há definição quanto ao texto final e a solução virá por Medidas Provisórias, segundo consta. De qualquer for-

144 A íntegra do Projeto encontra-se in DeLucca/Internet, p. 495 e seg. e o art. 4, p. 495 e 496 145 Dispunha o Art. 5 do referido projeto da OAB/SP, depois PL 1589:"Art. $5^{\circ}$ - O ofertante somente poderá solicitar do destinatário informações de caráter privado necessárias a efetivação do negócio oferecido, devendo mantê-las em sigilo, salvo se prévia e expressamente autorizado a divulgá-las ou cedê-las pelo respectivo titular. $\S 1^{\circ}-$ A autorização de que trata o caput deste artigo constará em destaque, não podendo estar vinculada à aceitação do negócio. $\S 2^{\circ}$ - Responde por perdas e danos o ofertante que solicitar, divulgar ou ceder informações em violação ao disposto neste artigo." Veja DeLucca/Internet, p. 496.

146 Assim o texto:" Art. $8^{\circ}$ - O envio de oferta por Mensagem eletrônica, sem prévio consentimento dos destinatários, deverá permitir a estes identificá-la como tal, sem que seja necessário tomarem conhecimento de seu conteúdo." Veja DeLucca/Internet, p. 496.

147 Assim o texto: "Art. $7^{\circ}$ - Os sistemas eletrônicos do ofertante deverão transmitir uma resposta eletrônica automática, transcrevendo a mensagem transmitida anteriormente pelo destinatário, e confirmando seu recebimento.” Veja DeLucca/Internet, p. 496.

148 Assim o texto: “Art. $6^{\circ}$ - A oferta pública de bens, serviços ou informações à distância deve ser realizada em ambiente seguro, devidamente certificado". Veja DeLucca/Internet, p. 496.

149 Assim o texto do "Art. 13, § $2^{\circ}$ - Deverão os ofertantes, no próprio espaço que serviu para oferecimento de bens, serviços e informações, disponibilizar área específica para fins do parágrafo anterior, de fácil identificação pelos consumidores, e que permita seu armazenamento, com data de transmissão, para fins de futura comprovação." Veja DeLucca/Internet, p. 497.

150 Em especial a referentes à participação dos notários, veja crítica em Carvalho, p. 128 e seg. e o Art. 13, com o seguinte texto: 'Art. 13 - Aplicam-se ao comércio eletrônico as normas de defesa e proteção do consumidor. $\S 1^{\circ}$ - Os adquirentes de bens, de serviços e informações mediante contrato eletrônico poderão se utilizar da mesma via de comunicação adotada na contrataçăo, para efetivar notificaçōes e intimações extrajudiciais, a fim de exercerem direito consagrado nas normas de defesa do consumidor. $\S 2^{\circ}$ - Deverão os ofertantes, no próprio 
ma, destaque-se que a melhor solução foi a dada pela Diretiva 97/7/CE sobre contratação à distância, que assegura um extenso direito de informação do consumidor e sanciona eventuais falhas no cumprimento deste dever de informar a um aumento do prazo de reflexão para o consumidor. ${ }^{151}$ A Diretiva 2000/31/CE, traz deveres de informação nos Art. $5^{\circ}, 6^{\circ} \mathrm{e}$ 10 e o dever de confirmação da aceitação no Art. $11^{\circ}$, direitos de privacidade e de não receber produtos, no Art. $7^{\circ} \mathrm{e}$ regras especiais sobre a conclusão dos contratos por meio eletrônico (Art. $9^{\circ}$ ), como veremos a seguir. Também nos EUA, o Electronic Signatures in Global and $\mathrm{Na}$ tional Commerce Act, de 8 de junho de 2000 , assegura direitos de informação, de disclosure dos termos do negócio e direito de reflexão ao consumidor.
Norbert Reich destaca que importante para o consumidor é o tempo da informação, o modo e clareza da informação, a língua, sua identificação e sua imputabilidade ao fornecedor. ${ }^{152}$ Repita-se que, aplicando o Código de Defesa do Consumidor e as linhas gerais de boa-fé aqui especificadas, em uma visão contratual renovada, parece-me que podemos impor os mesmos deveres de conduta de boa-fé aos fornecedores no mercado eletrônico brasileiro, mesmo antes da aprovação de lei específica. ${ }^{153}$

Quanto à aceitação entre ausentes, ${ }^{154}$ - CDC nada regula, assim, aplicáveis as normas subsidiárias da legislação geral. Segundo o Código Civil Brasileiro de 1916, em seu Art. 1.086, e o novo Código Civil de 2002, em seu artigo $434,{ }^{155}$ o contrato torna-se perfeito quando da ex-

espaço que serviu para oferecimento de bens, serviços e informaçoes, disponibilizar área específica para fins do parágrafo anterior, de fácil identificação pelos consumidores, e que permita seu armazenamento, com data de transmissão, para fins de futura comprovação. $\S 3^{\circ}-\mathrm{O}$ prazo para atendimento de notificação ou intimação de que trata o parágrafo primeiro começa a fluir da data em que a respectiva mensagem esteja disponível para acesso pelo fornecedor. $\S 4^{\circ}-$ Os sistemas eletrônicos do ofertante deverão expedir uma resposta eletrônica automática, incluindo a mensagem do remetente, confirmando o recebimento de quaisquer intimaçōes, notificações, ou correios eletrônicos dos consumidores". Veja DeLucca/Internet, p. 497.

151 Assim também MEENTS, p. 200 e REICH/NORDHAUSEN, p. 198.

152 Assim REICH/NORHAUSEN, p. 187 a 193.

153 Assim também concluiu SANTOLIM, p. 36 e 37, CARVALHO, Ana Paula Gambogi, Contratos via Internet. Belo Horizonte: Del Rey, 2001 p. 147 e Roberto SENISE, in DeLucca/ Internet, p. 488, também DeLucca/Internet, p. 94 e seg., esclarecendo, porém, a necessidade de normas específicas. Sobre o consenso internacional da imposição da boa-fé à atuação dos fornecedores neste meio, veja LORENZETTI, Comeércio eletrónico, p. 246 e 247. Veja o advogado da Microsoft SMITH, p. 324 ponderando os efeitos "econômicos" positivos da aplicação da boa-fé e princípios gerais de proteção dos mais fracos no comércio eletrônico: "Traditional consumer protection principles - such as the obligations to provide relevant information, engage in honest and fair practices, and respect consunmer privacy - ave generated a common understanding of commercial practices that help provide stability, predicability, and consumer and investors confidence. Adherence to theses principles is equally valuable online.

154 Critica, com razão, esta terminologia, BARBAGALO, p. 26 e seg.

155 Assim o texto: "Art. 434. Os contratos entre ausentes tornam-se perfeitos desde que a aceitação é expedida, exceto: I - no caso do artigo antecedente; II - se o proponente se houver comprometido a esperar resposta; III - se ela não chegar no prazo convencionado. 
pedição da aceitação pelo consumidor, a qualquer momento, dentro das condições da oferta não retirada devidamente. ${ }^{156}$ Já entre presentes a aceitação deve ser imediata, o que é bastante complicado em caso de ofertas interativas (em Internet Realy Chat) ${ }^{157}$ No caso das ofertas entre ausentes, aplicáveis são as normas do CDC (Arts. 30, 34, 35 e 48 do Código de Defesa do Consumidor), em preferência ao Art. 1081 do CCB e as novas normas do Código Civil de 2002 (Arts. 427 e seg.), resultando em uma força vinculativa face à teoria da declaração e da confiança, muito maior que se pode supor no primeiro momento. ${ }^{158}$

\subsubsection{Interpretação dos contratos e direito de arrependimento como lei de aplicação imediata}

A doutrina é unânime que a interpretação dos contratos do comércio eletrô- nico envolvendo consumidores deve ser diferenciada, sensível à proteção do contratante mais fraco e leigo, o consumidor. ${ }^{159} \mathrm{~A}$ interpretação se faz a seu favor (Art. 47 do CDC) e o recurso ao direito subsidiário geral só se fará quando favorável ao consumidor. Assim, por exemplo, enquanto no direito civil geral a regra é que "o silêncio importa anuência, quando as circunstâncias ou os usos o autorizarem, e não for necessária a declaração de vontade expressa" (Art. 1084 do. CCB/16 e Art. 11 do CCB/ 2002), no direito do consumidor a regra é inversa: o silêncio do consumidor significa negação e indício que aconteceu uma prática abusiva do fornecedor. ${ }^{160}$ Aqui incluem-se as práticas de envio de produtos e serviços não solicitados. Neste sentido, pode-se afirmar que, no mundo virtual, o silêncio não significa aceitação dos consumidores e sim indício de que um ato comercial dos fornecedores

156 Veja detalhes in CARVALHO, p. 149.

157 Veja em CARVALHO, p. 86 e 87, quais são as ofertas na Internet consideradas entre presentes (interativas) e quais entre ausentes (e-mail, sites, etc.): “Ofertas transmitidas ao oblato por meio de Internet Relay Chat, ou seja, de forma interativa, devem ser consideradas, como no caso de ofertas feitas por telefones, inter presentes. Por outro lado, devem ser consideradas inter absentes as ofertas transmitidas ao solicitado por e-mail ou por "clique" em uma homepage, hipóteses em que ocorre um lapso temporal significativo entre a exteriorização da oferta e a sua chegada à esfera do conhecimento do oblato."

158 Veja minhas críticas ao livro de CARVALHO, p. 308 e 309.

159 Assim diferenciam o comércio B2B do B2C: VIVANT, p. 173, FÉRAL-SCHUHL, p. 147 e seg., LORENZETTI, Comeércio Eletrónico, p. 218 e seg., BRIZZIO, p. 42, MAYER/Partie Faible, p. 514 e seg., MEENTSz, p. 179 e seg., REICH/NORDHAUSEN, p. 2 e seg., Köhler/ Arndt, p. 35 e seg., HÄRTING, p. 67 e seg., no Brasil, SANTOLIM, p. 37 e seg., SANTOS e ROSSI, p. 118 e seg., DELUCCA/Internet, p. 89, e seg., SIMÃO, p. 101 e seg., PODESTÁ, p. 162 e seg., LUCON, p. 354 e seg., SENISE, p. 488, LOTUFFO, p. 222, GRECO, Marco Aurélio, Direito e Internet, São Paulo: Dialética, 2000, p. 49 e seg e LUCON, Rodrigo, A Internet e as Relações de Consumo. Internet: o direito na era virtual, SCHOUERI, Luis Eduardo (Org.), Rio de Janeiro: Forense, 2001, p. 3.

160 Assim, por exemplo, se o consumidor recebe um produto que não pediu e mantêm o seu "silêncio", o direito positivo brasileiro atual (Art. 39 do CDC) não pressupõe que sua passi- 
pode ser abusivo, e violar a confiança dos consumidores frente aos profissionais, os fornecedores do comércio eletrônico. A vontade do consumidor neste meio pode ser expressa por palavras ou atos (tocar símbolos, ícones, fazer clicks - point and click agreements, click-wrap agreements - e condutas sociais típicas, etc.), mas não presumida do silêncio. ${ }^{161}$ Aqui há também que se considerar as linhas de presunção da identidade do agente contratante, tanto fornecedor, como consumidor, onde as atuais linhas de boa-fé impõem aplicação das teorias da aparência (para o profissional, já que se aplica o Direito Comercial) e da confiança (para o consumidor-leigo). ${ }^{162}$ Dentre os contratos que merecem uma interpretação especial estão os que envolvem jogos de azar, prêmios, conteúdos pornográficos e de lazer, geralmente envolvendo a ordem pública dos países conectados. ${ }^{163}$
A doutrina é unânime que aos contratos à distância do comércio eletrônico se aplica o Art. 49 do CDC e o prazo de reflexão de 7 dias. ${ }^{164}$ A doutrina ainda cuida da forma da contratação eletrônica, concluindo que o contrato é por escrito e há a qualidade de documento ao documento eletrônico, ${ }^{165}$ do lugar da contratação (tema bastante polêmico, se aplicáveis as normas de Direito Internacional Privado, como veremos a seguir), ${ }^{166} \mathrm{da}$ assinatura eletrônica, ${ }^{167}$ da eficácia probatória dos documentos eletrônicos, ${ }^{168} \mathrm{da}$ responsabilidade dos intermediários e do organizador da cadeia de fornecimento pela Internet ${ }^{169} \mathrm{e}$ das garantias no comércio eletrônico. Aqui, parece-me, mais importante, com a crescente internacionalização das relações de consumo na Internet, tratar da lei aplicável a esta contratação, pois é esta lei aplicável que estabelecerá os limites e regras para a proteção do sujeito mais fraco, o consumidor, nes-

vidade seja aceitação, ao contrário, pune o fornecedor, afirmando que o produto (por exemplo, livros ou cartão de crédito enviado sem requisição específica) será considerado uma amostra "grátis", conforme a lista de práticas comerciais abusivas proibidas pelo CDC (Art. 39 , III c/c § único).

161 Assim afirmou COUTO E SILVA, Clóvis do, Obrigação como Processo, São Paulo: Bushasky, 1972, p. 26: "É manifesto, assim, que a autonomia da vontade e a teoria das fontes das obrigações, que com ela se vincula, se encontram em período de transformação e de reelaboração dogmática. De um lado, a intervenção estatal, de outro, a tipificação social, e sobretudo os atos jurídicos de caráter existencial, forçaram a revisão dos conceitos."

162 Sobre o tema, veja magistral, LORENZETTI, Ricardo, Comércio eletrónico, p. 219 e seg e, no Brasil, GREGO, p. 30 e seg.

163 Sobre o tema, veja WIMMER/MICHAEL, p. 40 e seg.

164 Veja, por todos, BENEVIDES DE CARVALHO, p. 104 a 106.

165 Assim MEENTS, p. 51 e seg.

166 Trataremos do tema em detalhes a seguir, mas veja, com opiniões contrárias, BARBAGALO, p. 77 e seg.

167 Sobre o tema, veja livro específico de Davi Monteiro DINIZ, Davi Monteiro, Documentos Eletrônicos: Assinaturas Digitais, São Paulo: LTr, 1999.p. 11 e seg.

168 Veja CARVALHO, p. 150 a 152.

169 Veja minha rescensão ao livro de Carvalho, in RDC 40, p. 309 e 310. 
te meio tão fluido, que é o eletrônico. Como asseverou o mestre da UFRGS, Clóvis do Couto e Silva: "A liberdade absoluta de contratar, sem legislação marginal ao mercado, que harmonizasse as forças econômicas em litígio, ocasionou, nos países altamente industrializados, profundas restrições ao princípio da autonomia da vontade. Os particulares se viam não só forçados a não poder escolher com quem contratar - 'Organizationzwang' -- como igualmente se lhes impossibilitava o diálogo a respeito do conteúdo do contrato." ${ }^{170}$ Em outras palavras, se o meio virtual, a rede da Internet e a globalização aumentam a liberdade teórica dos consumidores, a prática lhes limita e a solução só pode ser a regulamentação pelo Direito.

Especial atenção merece o fato do mandamento de proteção do consumidor, como direito fundamental a obrigar o Estado-Legislador, o Estado-Juiz e o Estado-Executivo a uma ação positiva na tutela destes agentes vulneráveis do mercado brasileiro, estar incluído no inciso XXXII do Art. $5^{\circ}$ da Constituição Federal, artigo que em seu caput assegura estes direitos a brasileiros e a estrangeiros residentes no Brasil. Daí se retira que a nova ordem pública constitucional brasileira inclui necessariamente a "defesa do consumidor." A pergunta é o grau, nível ou standard desta proteção em casos de Direito Internacional Privado. Em outras palavras, se em casos pluriconectados todas as normas do Código Brasileiro de Defesa do Consumidor seriam imperati- vo ou de ordem pública internacional (grau total de aplicação), ou se somente a preocupação de "defesa do consumidor" seria obrigatória, podendo ser alcançada pela aplicação eventual de uma lei estrangeira, pelas normas da LICC/42; ou o nível de defesa do consumidor, alcançado pelo CDC, é considerado, face a sua origem constitucional (Art. 48 ADCT), como obrigatório a tutelar os brasileiros e estrangeiros (pessoas físicas) residentes no Brasil, standard mínimo de "defesa do consumidor", que leva à aplicação imediata destas normas tutelares, que, porém, não impedem que outras estrangeiras sejam aplicadas, se asseguram nível superior de defesa ao alcançado pelo CDC. ${ }^{171}$

Dando preferência à última hipótese, cabe especificar que as chamadas "leis de aplicação imediata" são leis básicas de segurança do mercado ou sociedade (sauvegarde de l'organisation politique, sociale ou économique du pays), leis para nacionais e estrangeiros e para todas as relações privadas, sem necessidade de antes passar pelo método clássico do Direito Internacional Privado, da indicação de uma lei aplicável. Esta própria lei "de aplicação imediata" ou lei de "polícia" tem pretensões de aplicação genérica e extraterritorial sempre, não importando se são leis de direito privado ou público, uma vez que positivam fortes interesses de organização da sociedade nacional. Como a chamada lei de aplicação imediata é direta ou resolve o conflito diretamente, sua aceitação

170 COUTO E SILVA, Clóvis V. do. A Obrigação como Processo. São Paulo: Bushatsky, p. 25. 171 Veja HOFFMAN, Bernd von. Über den Schutz des Schächeren bei Internationalen Schuldvertragen. Rabelsz, 38, 1974, p. 401 e seg. 
e identificação hierárquica dentro do DIPr. é uma técnica (por sinal cada vez mais usada) de "materialização" das novas regras de conflitos de leis.

\section{CONCLUSÃO E TESES PARA VOTAÇÃO}

Concluindo, pois, esta minha exposição sobre tema ainda candente e em evolução, submeto ao plenário três teses, esperando que possam ser aprovadas pelos colegas:

1. Ao comércio eletrônico realizado por consumidores domiciliados no Brasil aplica-se prioritariamente o Código de Defesa do Consumidor, e só subsi- diariamente, no que couber, o atual Código Civil de 1916 e o Novo Código Civil (Lei 10406/2002), quando entrar em vigor.

2. Em Direito Internacional Privado, deve-se considerar o Código de Defesa do Consumidor como lei de aplicação imediata, a exemplo da decisão do STJ no Resp. 63.981-SP (Rel. Min. Sálvio de Figueiredo Teixeira, j. 04.05.2000).

3. O Projeto de Lei sobre comércio eletrônico elaborado pela OAB/SP impõe normas necessárias para regular aspectos específicos das relações de consumo contratadas por meio eletrônico e merece aprovação no Congresso Nacional, com eventuais mudanças atualizadoras. 